\title{
O gênero Epidendrum L. (Orchidaceae) no Estado do Paraná, Brasil ${ }^{1}$
}

\author{
Juliane Franzen Stancik ${ }^{2,4}$, Renato Goldenberg ${ }^{2}$ e Fábio de Barros ${ }^{3}$
}

Recebido em 14/05/2007. Aceito em 30/01/2009

RESUMO - (O gênero Epidendrum L. (Orchidaceae) no Estado do Paraná, Brasil). Este trabalho teve como objetivo fornecer dados sobre a composição florística, morfologia e distribuição das espécies do gênero Epidendrum no estado do Paraná, Brasil. São apresentadas: chave de identificação e descrições das 22 espécies de Epidendrum ocorrentes. Epidendrum saximontanum Pabst é registrado pela primeira vez para o estado.

Palavras-chave: Brasil, Epidendrum, Orchidaceae, Paraná, taxonomia

ABSTRACT - (The genus Epidendrum L. (Orchidaceae) in Paraná State, Brazil). The goal of this work is to supply data on the floristic composition, morphology and species distribution of the genus Epidendrum in Paraná state, Brazil. An identification key and descriptions of the 22 species of Epidendrum are presented. The occurrence of Epidendrum saximontanum Pabst is recorded for the first time in the state. Key words: Brazil, Epidendrum, Orchidaceae, Paraná state, taxonomy

\section{Introdução}

A família Orchidaceae possui cerca de 24.500 espécies (Dressler 2005) distribuídas por quase todo o mundo, mas apresentando maior concentração e diversidade nas regiões tropicais e subtropicais. Epidendroideae é a maior das cinco subfamílias, com um número de gêneros e espécies superior ao de todas as outras subfamílias juntas, e tem como principal característica a antera geralmente incumbente (Dressler 1993). O gênero Epidendrum L., com aproximadamente 1.000 espécies, ocorre desde o sul dos Estados Unidos até a Argentina (Rasmussen 1985), e tem como principais características diferenciais os caules longos, eretos e finos, raramente intumescidos em pseudobulbos, as folhas geralmente dísticas, as margens ventrais do ginostêmio coalescentes com o unguículo do labelo, e o rostelo fendido e mais ou menos paralelo ao eixo do ginostêmio. No Brasil ocorrem 107 espécies (Pabst \& Dungs, 1975) e no Paraná, 22.

Nos últimos 30 anos, vários estudos tratando de Epidendrum foram realizados, gerando várias publicações, porém a maioria delas constituindo notas taxonômicas de uma espécie (Dunsterville 1979; Dressler 1989) ou de um pequeno grupo delas (Brieger 1978; Sastre 1990a; b; 1991; Hágsater 1993; 2001; Saldaña \& Hágsater 1996; Hágsater et al. 2005). No Brasil, os trabalhos taxonômicos de maior importância são os de Cogniaux (1893-1896) e de Pabst \& Dungs $(1975 ; 1977)$, antigos e de difícil acesso, mas ainda duas das mais significativas obras sobre as orquídeas brasileiras. Para o Paraná não há trabalhos relevantes sobre o gênero, apenas aqueles que trazem listas de espécies ocorrentes no estado, como é o caso de Angely (1956) e Schlechter (1926; 1944).

Muitos trabalhos vêm sendo realizados sobre as orquídeas brasileiras nos últimos anos, contribuindo para o conhecimento taxonômico da família, porém a maioria é representada por descrições de novos táxons ou indicações de novas ocorrências. Aqui é proposto um tratamento taxonômico de Epidendrum, um dos gêneros maiores e mais problemáticos da família, que poderá servir como guia de identificação em levantamentos florísticos e estudos afins realizados no Paraná. Objetivou-se, também, fornecer dados sobre a composição florística, morfologia e distribuição das espécies do gênero no Paraná.

\section{Material e métodos}

Área de estudo - O estado do Paraná situa-se entre as coordenadas $22^{\circ} 29^{\prime} 30^{\prime \prime}-26^{\circ} 42^{\prime} 59^{\prime \prime}$ S e 48 $02^{\prime} 24^{\prime \prime}-54^{\circ} 37^{\prime} 38^{\prime \prime}$ W. Ao norte limita-se com o estado de São Paulo, a leste com a orla do oceano Atlântico, ao sul com o Estado de Santa Catarina e a oeste com o Estado do Mato Grosso do Sul, além de Paraguai e Argentina (Maack 1981).

Em sua maior extensão, o Estado do Paraná é formado de escarpas de estratos e planaltos que declinam suavemente em direção oeste e noroeste. Em virtude da posição das escarpas, dos vales dos rios e dos divisores de água, podem ser distinguidas cinco grandes regiões de paisagens naturais: o litoral, a Serra do Mar, o primeiro planalto ou planalto de Curitiba, o segundo planalto ou planalto de Ponta Grossa, e o terceiro planalto ou planalto de Guarapuava. O litoral e o primeiro planalto são separados por uma zona de serra que acompanha a grande escarpa de falha do complexo cristalino (Maack 1981).

Segundo Velloso et al. (1991) os principais tipos de vegetação ocorrentes no Paraná são: 1) Floresta Ombrófila Densa, no litoral e Serra do Mar, com os subtipos de floresta Altomontana (altitudes superiores a $1.000 \mathrm{~m}$ ), Montana (altitude entre 400 e $1.000 \mathrm{~m}$ ), Submontana (altitude entre 30 e $400 \mathrm{~m}$ ) e de Terras Baixas (até $30 \mathrm{~m}$ de altitude), além de formações associadas (refúgios ou campos de altitude; formações pioneiras ou restinga e mangue); 2) Floresta Ombrófila Mista (ou Mata com Araucária), nas regiões mais altas ao sul da região planaltina; 3) Estepe Ombrófila (ou "Campos Gerais") nas mesmas regiões; 4) Floresta Estacional Semidecidual Subxérica (norte e oeste do Segundo e Terceiro Planaltos); 5) Savana Estacional Subxérica (ou cerrado), no nordeste do estado.

Coleta de dados - Este trabalho foi baseado na análise morfológica de exsicatas e exemplares coletados em diversas localidades do estado. Foram consultadas as coleções de Epidendrum coletadas no Paraná, dos seguintes herbários nacionais: CESJ, FUEL, HB, HUM, ICN, MBM, PKDC, R, RB, SP e UPCB (siglas segundo Holmgren et al. 1990). As descrições foram feitas, sempre que possível, baseadas apenas em material proveniente do Paraná (listado em "Material selecionado ou examinado"). Quando este foi considerado insuficiente, foram utilizados

\footnotetext{
1 Parte da Dissertação de Mestrado da primeira Autora

2 Universidade Federal do Paraná, Departamento de Botânica, Setor de Ciências Biológicas, Curitiba, PR, Brasil

3 Instituto de Botânica, São Paulo, SP, Brasil

4 Autora para correspondência: jstancik@hotmail.com
} 
materiais de estados vizinhos (neste caso, indicados em "Material adicional"). Para a terminologia morfológica foram utilizados Radford et al. (1974), e Dressler (1981) para terminologias específicas da família Orchidaceae. A classificação adotada foi a mesma utilizada por Pabst \& Dungs (1975).

As informações referentes a aspectos ecológicos foram retiradas das exsicatas e de observações feitas em campo, e a classificação adotada para os tipos vegetacionais foi a de Roderjan et al. (1998). A distribuição geográfica geral, para cada espécie amostrada, foi seguida aquela apresentada por Pabst \& Dungs (1975).

\section{Resultados e discussão}

Epidendrum L., Sp. Pl. ed. 2, p.1347. 1763.

Plantas epífitas, terrestres ou rupícolas, eretas ou pendentes. Caule não espessado em pseudobulbo, simples ou ramificado, compresso ou cilíndrico, recoberto por folhas e bainhas das folhas; rizoma curto ou longo. Folhas em geral numerosas, dísticas ou equitantes ao longo do caule, coriáceas, subcoriáceas, cartáceas, submembranáceas ou membranáceas, planas, ligeiramente conduplicadas ou côncavas, elíptico-lineares, elípticas, linear-ovadas, linearlanceoladas, ovadas, oblongas, obovadas ou lanceoladas, ápice arredondado, agudo, apiculado, ou retuso. Inflorescência apical, em racemo, corimbo ou panícula, ereta ou pendente, base envolvida ou não por brácteas. Flores alaranjadas, alvacentas, amarelas, creme, cremeesverdeadas, lilases, róseas, verdes ou vermelhas; sépalas iguais ou não entre si, livres, planas ou côncavas; pétalas semelhantes às sépalas, normalmente um pouco mais estreitas, livres, planas ou ligeiramente côncavas, margens lisas ou onduladas; labelo inteiro, trilobado ou tripartido, plano ou conduplicado, margens lisas, fimbriadas ou onduladas; calos presentes ou ausentes no disco do labelo; ginostêmio adnado ao unguículo do labelo; polínias 4, ceróides, lateralmente achatadas, com caudículas; ovário com ou sem nectário do tipo cunículo, este, quando presente, proeminente ou não. Frutos elipsóides, ovóides, globóides, ou fusiformes.

Para o Brasil, são citadas em torno de 100 espécies do gênero, distribuídas por todo o país, em regiões com os mais diversos tipos climáticos e vegetacionais. Geralmente ocorrem em altitude média, de 100 a 1.250 m (Pabst \& Dungs 1975).

Para o Estado do Paraná, Pabst \& Dungs (1975) citam 31 espécies de Epidendrum. No entanto, neste trabalho, das 31 espécies citadas, apenas 21 foram constatadas, além de uma nova ocorrência. As demais espécies citadas: Epidendrum aquaticum Lindl., E. crassifolium Lindl., E. difforme Jacq., E. ecostatum Pabst, E. ellipticum Grah., E. nutans Sw., E. obergii Hawkes, E. ochrochlorum Barb. Rodr., E. paniculatum Ruiz \& Pav., E. pedale Pabst, E. pseudavicula Kraenzl., E. purpureum Barb. Rodr., E. rodriguesii Congn. e E. versicolor Hoehne \& Schltr., que serão discutidas posteriormente, não foram confirmadas, ou por representarem variações morfológicas em alguns grupos mais complexos, ou por se tratar de determinações incorretas, devido às semelhanças com espécies afins. Espécies de Epidendrum ocorrem em todas as regiões do estado, porém, apresentam forte predominância nas regiões da Planície Litorânea e Serra do Mar. Da mesma forma, ocorrem em todas as formações vegetacionais, mas principalmente em Floresta Ombrófila Densa.

Pabst \& Dungs (1975) apresentaram uma classificação subgenérica informal em Epidendrum composta por: quatro seções, oito grupos e 26 "alianças". Todas as espécies ocorrentes no Paraná fazem parte da seção II Epidendrum, caracterizada por caules não espessados e folhas dísticas.

As espécies do grupo Spathaceae, E. armeniacum Lindl. e E. cristatum Ruiz \& Pav., apresentam inflorescência com a base envolvida por grandes brácteas. A primeira delas pertence à "Aliança E. armeniacum", caracterizada por apresentar flores de cerca de $6 \mathrm{~mm}$ de diâmetro; e a segunda, à "Aliança E. cristatum", na qual as inflorescências apresentam pedúnculo mais curto que o racemo pendente.

O grupo Racemosae, representado por E. geniculatum Barb. Rodr., E. henschenii Barb. Rodr. e E. proligerum Barb. Rodr., apresenta inflorescência em racemo, porém a base não é envolvida por brácteas conspícuas. Epidendrum geniculatum e E. henschenii fazem parte da "Aliança E. coronatum", que possui como características: o caule indiviso e a inflorescência pendente ou nutante. Já E. proligerum pertence à "Aliança E. proligerum" por apresentar o caule ramoso.

O grupo Filicaules, com apenas uma espécie representada no Paraná (E. caldense Barb. Rodr.) tem como características: os caules muito finos, de 1,5-2,0 $\mathrm{mm}$ de diâmetro.

O maior grupo, Amphyglottidae, possui inflorescência com pedúnculo muito longo, geralmente tão longo, ou quase, quanto o caule, e está representado no Paraná por E. ansiferum Rchb. f., E. denticulatum Barb. Rodr., E. fulgens Brongn., E. puniceoluteum F. Pinheiro \& F. Barros e E. secundum Jacq. Na "Aliança E. schomburgkii", caracterizada pelo labelo trilobado, com lobos laterais ciliados ou denticulados e lobo mediano com lamela longitudinal, estão as espécies: E. fulgens e E. puniceoluteum. Pabst \& Dungs (1975) posicionam E. secundum na "Aliança E. polyanthum", que engloba espécies que possuem o labelo trilobado com margens inteiras. A espécie que, neste trabalho, está sendo tratada sob o binômio E. secundum, é o que Pabst \& Dungs (1975) denominam E. crassifolium Lindl., pertencente à "Aliança E. denticulatum" que possui como características principais: labelo trilobado, lobos ciliados ou denticulados e lobo mediano com calosidade, mas sem lamela longitudinal. Fazem parte dela $E$. ansiferum e E. denticulatum.

O grupo Subumbellatae apresenta flores sésseis, solitárias ou aglomeradas. Epidendrum nocturnum Jacq. faz parte da "Aliança E. nocturnum", na qual o labelo é trilobado com o lobo mediano linear ou acicular. Já E. latilabre Lindl. e E. pseudodifforme Hoehne \& Schltr. pertencem à "Aliança E. difforme" caracterizada pelo labelo inteiro ou apenas exciso no ápice. 
O grupo Paniculatae, representado por: E. dendrobioides Thunb. e E. densiflorum Hook., possui inflorescência paniculada. Pabst \& Dungs (1975) listam como características da "Aliança E. aquaticum", à qual pertence E. dendrobioides, o labelo largamente trilobado, cordiforme e conduplicado. No entanto, neste trabalho, o labelo de E. dendrobioides caracterizou-se inteiro. Epidendrum densiflorum está posicionado na "Aliança E. paniculatum", a qual é caracterizada por apresentar o labelo tetralobado. Porém, no presente levantamento, o labelo de E. densiflorum apresentou-se trilobado a tetralobado.
O grupo Strobiliferae é caracterizado por apresentar grandes brácteas florais imbricadas que cobrem todo o ovário e parte da flor. A "Aliança E. rigidum", com plantas eretas de rizoma longo e caule não ramificado, está representada por E. rigidum Jacq. Já E. ramosum Jacq., E. paranaense Barb. Rodr., E. saximontanum Pabst e E. strobiliferum Rchb.f. fazem parte da "Aliança E. ramosum", caracterizada por plantas pendentes, ramificadas e flores em racemos.

O grupo Equitantes está representado no Paraná apenas por E. vesicatum Lindl. que apresenta o caule pendente e as folhas imbricadas, com as apicais cobrindo as flores.

Chave de identificação para as espécies de Epidendrum do Estado do Paraná

1. Caule pendente

2. Folhas côncavas ou conduplicadas

3. Folhas côncavas, $3,5-12,8 \times 1,3-6,0 \mathrm{~cm}$

22. E. vesicatum

3. Folhas conduplicadas, $0,6-1,2 \times 0,2-0,45 \mathrm{~cm}$.

19. E. saximontanum

2. Folhas planas a ligeiramente conduplicadas

4. Brácteas florais cobrindo o pedicelo, e até parte da flor, sem esconder o eixo da inflorescência

17. E. ramosum

4. Brácteas florais cobrindo o pedicelo, e até parte da flor, escondendo o eixo da inflorescência

5. Caule 14-80 cm compr.; folhas 4,5-15,5×1,1-3,0 cm; flores com sépalas e pétalas de $1 \mathrm{~cm}$ compr. ou maiores

13. E. paranaense

5. Caule 2-12 cm compr.; folhas 0,7-2,8×0,3-0,8 cm; flores com sépalas e pétalas menores que $1 \mathrm{~cm}$ compr.

21. E. strobiliferum

1. Caule ereto

6. Caule ramificado

7. Folhas coriáceas; base da inflorescência envolta por brácteas de ca. $1 \mathrm{~cm}$ compr.; brácteas florais cobrindo o pedicelo e até parte da flor; flores creme-esverdeadas, com sépalas e pétalas menores que $0,9 \mathrm{~cm}$ compr. .

5. E. dendrobioides

7. Folhas membranáceas; base da inflorescência não envolta por brácteas; brácteas florais cobrindo até a metade do pedicelo; flores verdes, com sépalas e pétalas maiores que $0,9 \mathrm{~cm}$ compr...... 14. E. proligerum

6. Caule simples

8. Inflorescência encurvada a pendente

9. Brácteas da base da inflorescência menores que $2 \mathrm{~cm}$ compr

10. E. henschenii

9. Brácteas da base da inflorescência maiores que $2 \mathrm{~cm}$ compr.

10. Sépalas e pétalas verde-amareladas; labelo verde-amarelado, menor que $1 \mathrm{~cm}$ compr., conduplicado, lobos laterais de margem ligeiramente ondulada e lobo mediano lanceolado a deltóide de margem inteira

2.E. armeniacum

10. Sépalas e pétalas verdes; labelo creme com pintas vinosas, maior que $1 \mathrm{~cm}$ compr., plano, lobos laterais de margem ondulada e duas aurículas, e lobo mediano bilobulado de margem ondulada

4. E. cristatum

8. Inflorescência ereta

11. Inflorescência em corimbo

12. Sépalas e pétalas lilases a róseas

13. Labelo com um calo, constituído por duas saliências ovóides, basais, e uma lamela

longitudinal central, de coloração creme

7. E. denticulatum

13. Labelo com um calo inteiriço, variadamente lobulado, de coloração alva e/ou amarela

20. E. secundum

12. Sépalas e pétalas predominantemente vermelhas, alaranjadas ou amarelas

14. Sépalas e pétalas vermelhas, menores que $1 \mathrm{~cm}$ compr.; labelo com um calo inteiriço, alongado, variadamente lobulado

1. E. ansiferum

14. Sépalas e pétalas amarelas, alaranjadas ou vermelhas, de $1 \mathrm{~cm}$ compr. ou maiores; labelo com calo constituído por duas saliências ovóides, basais e uma lamela longitudinal central 
15. Sépalas e pétalas amarelas a vermelhas; labelo com lobos laterais suborbiculares, margem denticulada, lobo mediano retangular a deltóide, emarginado a profundamente emarginado, istmo inconspícuo

15. Sépalas e pétalas vermelho-purpúreas; labelo com lobos laterais obtriangulares, margem denticulada, lobo mediano obtriangular, bilobulado, istmo bastante conspícuo. 16. E. puniceoluteum

11. Inflorescência em panícula ou racemo

16. Pedúnculo da inflorescência ca. $1 \mathrm{~cm}$ de compr.

17. Sépalas e pétalas creme-esverdeadas; labelo trilobado, com o lobo mediano lineartriangular, agudo no ápice 12. E. nocturnum

17. Sépalas e pétalas verdes; labelo trilobado, com o lobo mediano suborbicular, fendido no ápice

18. Caule estreito na base e espessando para o ápice; labelo 1,6-3,2×2-4 cm, refletido 11. E. latilabre

18. Caule com a mesma espessura da base ao ápice; labelo ca. 1,1×1,2 cm, sub-patente 15. E. pseudodifforme

16. Pedúnculo da inflorescência maior que $1 \mathrm{~cm}$ compr.

19. Labelo trilobado a tetralobado

20. Sépalas e pétalas lilases a róseas com calo alvo e/ou amarelo 20. E. secundum

20. Sépalas e pétalas verdes a alvacentas

21. Sépalas e pétalas verdes; labelo verde, com calo constituído por duas saliências ovóides basais 3. E. caldense

21. Sépalas e pétalas verde-claras a alvacentas; labelo creme, com calo constituído por duas saliências arredondadas, basais, e uma lamela longitudinal central, da base ao ápice do labelo 6. E. densiflorum

19. Labelo inteiro

22. Sépalas e pétalas de coloração creme; labelo ca. $1,1 \times 0,55 \mathrm{~cm}$, deltóide-espatulado 9. E. geniculatum

22. Sépalas e pétalas verdes; labelo $0,6-0,8 \times 0,3-0,4 \mathrm{~cm}$, cordiforme 18. E. rigidum

1. Epidendrum ansiferum Rchb. f., Bonplandia 2: 111. 1854. Fig. 1

Terrestre ou rupícola, ereta. Caule 30-62 cm compr., simples, cilíndrico, ca. 0,6 cm diâm., espessura constante; rizoma não observado. Folhas 5,2-12×1-2,4 cm, dísticas, coriáceas, ovadas a lanceoladas, planas, ápice arredondado. Inflorescência 6-48,5 cm compr., em corimbo, apical, ereta, base do pedúnculo envolvida por brácteas com ca. $2 \mathrm{~cm}$ compr.; brácteas florais membranáceas, $0,3-0,8 \mathrm{~cm}$ compr., linear-triangulares a triangulares, cobrindo a base do pedicelo, ápice agudo. Flores 5-68 por inflorescência; pedicelo + ovário 1,2-3 cm compr., base não vesicada; sépalas vermelhas, a dorsal 0,7-0,9×0,25-0,4 cm, elíptica, plana, ápice agudo a apiculado, as laterais ca. $0,8 \times 0,35 \mathrm{~cm}$, lanceoladas, subfalcadas, planas, ápice agudo a apiculado; pétalas ca. $0,7 \times 0,25 \mathrm{~cm}$, vermelhas, estreitamente elípticas, margem inteira, ápice agudo a apiculado; labelo ca. $0,8 \times 0,7 \mathrm{~cm}$, vermelho, delgado, plano, trilobado, lobos laterais orbiculares, margem denticulada, istmo pouco evidente, lobo mediano obreniforme, margem denticulada, ápice emarginado, calo alvo e/ou amarelado, ca. 0,2 cm compr., inteiriço, alongado, variadamente lobulado, central; ginostêmio 0,4-0,6 cm compr. Fruto ca. 2,9×1,4 cm, elipsóide.

Material examinado: BRASIL. Paraná: Cerro Azul, 17/VIII/1966, Lindeman 2366 (HB, MBM).
Material adicional: BRASIL. São Paulo: Águas Mornas, 14/XII/1972, Klein 10550 (HB); Itapecerica, 6/V/1936, Gehrts.n. (RB87646); Serra da Bocaina, 3/V/1968, Sucre 2833 (HB, RB).

Observações: ocorre no Brasil (CE, PE, BA, GO, MG, ES, RJ, SP, PR, SC, RS). Coletada com flores em maio, agosto e dezembro. Ocorre no Paraná como terrestre ou rupícola em paredão de arenito em locais ensolarados de Floresta Ombrófila Densa Montana. A coloração vermelha de suas flores, pode confundi-la com E. fulgens Brongn. e E. puniceoluteum F. Pinheiro \& F. Barros. No entanto, estas duas espécies apresentam porte maior (até o dobro da altura da planta de $E$. ansiferum e flores de ca. $3 \mathrm{~cm}$ de diâmetro) e ocorrem na região de restinga, onde $E$. ansiferum não aparece. Epidendrum ansiferum também é muito próxima de outras duas espécies, E. denticulatum Barb. Rodr. e E. secundum Jacq. Neste caso ocorrem na mesma região, apresentam aproximadamente as mesmas dimensões e formato do labelo, porém $E$. denticulatum e $E$. secundum possuem flores lilases a róseas e a primeira delas, possui calo muito diferente, constituído apenas de duas calosidades arredondadas e uma lamelar central.

2. Epidendrum armeniacum Lindl., Edward's Bot. Reg. 22: tab. 1867. 1836.

= Amblostoma armeniacum (Lindl.) Brieger ex Pabst, Bradea 2(24): 168. 1977.

Fig. 2 
Epífita, ereta. Caule 6-19 cm compr., simples, compresso, 0,3-0,4 cm larg., espessura constante; rizoma inconspícuo. Folhas 2,4-14×0,4-1,7 cm, dísticas, coriáceas, elíptico-lineares a lanceoladas, planas, ápice agudo. Inflorescência 7-21,5 cm compr., em racemo, apical, encurvada a pendente, base do pedúnculo envolvida por 1-3 brácteas de 2,5-5 cm compr.; brácteas florais membranáceas, ca. $0,7 \times 0,05-0,1 \mathrm{~cm}$, lineartriangulares, cobrindo o pedicelo e parte da flor, ápice acuminado. Flores 50-70 por inflorescência; pedicelo + ovário ca. 0,5 cm compr., base não vesicada; sépalas verdeamareladas, a dorsal 0,3-0,4×0,1 cm, lanceolada, plana, ápice acuminado, as laterais $0,35-0,4 \times 0,1-0,12 \mathrm{~cm}$, lanceoladas, subfalcadas, ligeiramente côncavas, ápice agudo; pétalas $0,2-0,3 \times \mathrm{ca}$. $0,03 \mathrm{~cm}$, verde-amareladas, lineares a lineartriangulares, margem inteira, ápice arredondado a agudo; labelo ca. 0,4×0,1-0,2 cm, verde-amarelado, carnoso, conduplicado, trilobado, lobos laterais suborbiculares, margem ligeiramente ondulada, lobo mediano lanceolado a deltóide, margem inteira, ápice agudo; calo alvo, ca. $0,2 \mathrm{~cm}$ diâm., inteiriço, cordiforme, central; ginostêmio ca. $0,5 \mathrm{~mm}$ compr. Fruto não observado.

Material selecionado: BRASIL. Paraná: Antonina, 30/XI/1965, Hatschbach 13199 (HB); Guaraqueçaba, 13/VII/1999, Gatti 238 (UPCB); Morretes, 15/XII/1998, Kaehler 70 (UPCB); Paranaguá, 15/I/1970, Hatschbach 23342 (MBM); Piraquara, IV/1958, Leinig 26 (HB).

Observações: ocorre no Equador, Bolívia, Peru e Brasil (PE, MG, ES, RJ, SP, PR, SC, RS). Coletada com flores durante praticamente o ano todo. No Paraná, ocorre como epífita em locais sombreados, em Floresta Ombrófila Densa Montana e Submontana, e áreas de contato Estepe/Floresta Ombrófila Mista. Pode ser facilmente reconhecida por apresentar inflorescência em racemo, encurvada a pendente, com pequenas e numerosas flores verde-amareladas de aproximadamente $0,6 \mathrm{~cm}$ de diâmetro, caule estreito, reto e compresso, e brácteas longas na base da inflorescência, que cobrem praticamente todo o pedúnculo.

3. Epidendrum caldense Barb. Rodr., Gen. Sp. Orchid. 2: 148. 1881.

= Epidendrum paulense Cogn. in Mart., Fl. Bras. 3(5): 159. 1898.

= Epidendrum hatschbachii Schltr., Repert. Spec. Nov. Regni Veg. 23: 48. 1926.

Fig. 3

Epífita, ereta. Caule 4,5-19 cm compr., simples, cilíndrico, 0,1-0,2 cm diâm., espessura constante; rizoma inconspícuo. Folhas 2,2-7×0,25-0,8 cm, dísticas, cartáceas, elíptico-lineares a elípticas, planas, ápice apiculado. Inflorescência 2-3,5 cm compr., em racemo, apical, ereta, base do pedúnculo envolvida por 2 brácteas de ca. $1 \mathrm{~cm}$ compr.; brácteas florais membranáceas, 0,3-0,9×0,1 cm, lanceoladas a deltóides, cobrindo a base do pedicelo, ápice longamente acuminado. Flores 4-7 por inflorescência; pedicelo + ovário $0,4-1,5 \mathrm{~cm}$ compr., base não vesicada; sépalas verdes, a dorsal 0,7-1,2×0,15-0,3 cm, oblanceolada, plana, ápice agudo a arredondado, as laterais $0,6-1,2 \times 0,15-0,3 \mathrm{~cm}$, lanceoladas, subfalcadas, planas, ápice acuminado; pétalas $0,6-1,2 \times$ $0,1 \mathrm{~cm}$, verdes, linear-oblanceoladas, margem inteira, ápice agudo; labelo 0,7-2,45×0,4-2,5 cm, verde, delgado, plano, trilobado, lobos laterais suborbiculares, margem ligeiramente ondulada, lobo mediano oblongo-obtriangular, margem inteira, ápice arredondado; calo verde-claro, constituído por duas saliências ovóides com ca. 0,1 cm diâm., próximas entre si, basais; ginostêmio 0,5-0,7 cm compr. Fruto não observado.

Material examinado: BRASIL. Paraná: Campo Largo, IV/1961, Leinig 244 (HB); Curitiba, VI/1960, Leinig 197 (HB); São Jerônimo da Serra, III/1972, Seidel 1025 (HB); São José dos Pinhais, 16/III/1961, Seidel 1-61 (HB); Tibagi, 9/V/1953, Hatschbach 3252 (HB, MBM).

Observações: ocorre no Brasil (MG, SP, PR, SC, RS). Coletada com flores entre março e junho. No Paraná ocorre como epífita em Floresta Ombrófila Mista e em áreas de contato Estepe/Floresta Ombrófila Mista. Das espécies de Epidendrum que ocorrem no Paraná, é uma das mais fáceis de ser reconhecida vegetativamente, por apresentar caules eretos, muito finos, com até $0,2 \mathrm{~cm}$ de diâmetro, e folhas dísticas estreitas, características do "grupo Filicaules" (Pabst \& Dungs 1975), ao qual pertence.

4. Epidendrum cristatum Ruiz \& Pav., Syst. Veg. Fl. Peruv. Chil. 1:243. 1798.

= Epidendrum raniferum Lindl., Gen. Sp. Orchid. Pl. p.109. 1831.

= Epidendrum calliferum Lem., Jard. Fleur. 4: 65. 1853.

= Epidendrum hexadactylum Barb. Rodr., Gen. Sp. Orchid. 1:56. 1877.

= Epidendrum longovarium Barb. Rodr., Gen. Sp. Orchid. 1: 57. 1877.

= Epidendrum validum Schltr., Repert. Spec. Nov. Regni Veg. Beih. 9: 95. 1921.

Fig. 4

Epífita, ereta. Caule 33-64 cm compr., simples, compresso, 0,5-0,8 cm larg., espessura constante; rizoma curto, ca. $1 \mathrm{~cm}$. Folhas 5,5-17×1-2,8 cm, dísticas, coriáceas, elípticas, planas, ápice arredondado. Inflorescência 8-25,5 cm compr., em racemo, apical, pendente, base do pedúnculo envolvida por ca. 6 brácteas imbricadas de 3-7,5 cm compr.; brácteas florais membranáceas, 0,5-0,7×ca. $1 \mathrm{~cm}$, lanceoladas, cobrindo a base do pedicelo, ápice agudo. Flores 10-25 por inflorescência; pedicelo + ovário 2,5-4,5 cm compr., base não vesicada; sépalas verdes, a dorsal $1,7-2 \times 0,25-0,3 \mathrm{~cm}$, oblanceolada, plana, ápice arredondado a agudo, as laterais 1,5-1,8×0,28-0,5 cm, oblanceoladas, planas, ápice arredondado a agudo; pétalas 1,6-1,8×0,15-0,2 cm, verdes, linear-oblanceoladas, margem inteira, ápice arredondado a agudo; labelo 2,1-2,4×0,8-1,4 cm, creme com pintas vinosas, delgado, plano, trilobado, lobos laterais suborbiculares com 2 aurículas, margens onduladas, lobo mediano bilobulado, margem ondulada, ápice arredondado, calo ausente; ginostêmio 1,2-1,4 cm compr. Fruto não observado. 
Material selecionado: BRASIL. Paraná: Cerro Azul, 24/I/1974, Hatschbach 33753 (HB, MBM); Guaraqueçaba, 6/I/1970, Hatschbach 23296 (MBM); Guaratuba, 7/XII/1961, Hatschbach 8703 (MBM); Ipiranga, 16/II/1904, Dusén 3782 (R); Pontal do Paraná, II/1973, Leinig 510 (HB).

Observações: ocorre desde a América Central até o Sul do Brasil. Coletada com flores entre dezembro e fevereiro. No Paraná ocorre como epífita em locais sombreados, em Floresta Ombrófila Densa de Terras Baixas e Montana. Destaca-se por seu porte avantajado, com longos caules crescendo em touceiras. As inflorescências, com a base do pedúnculo quase totalmente recoberta por aproximadamente 6 brácteas imbricadas, sustentam até 25 flores perfumadas que abrem simultaneamente durante o verão.

5. Epidendrum dendrobioides Thunb., Pl. Bras. 2: 17. 1818. = Epidendrum carnosum Lindl., J. Bot. 3: 87. 1841 .

= Epidendrum durum Lindl., J. Bot. 3: 87. 1841.

Fig. 5

Terrestre, ereta. Caule 3-12 cm compr., ramificado, cilíndrico, 0,2-0,5 cm diâm., espessura constante; rizoma inconspícuo. Folhas $0,8-4,7 \times 0,45-1 \mathrm{~cm}$, coriáceas, ovadas a lanceoladas, planas, ápice agudo a curtamente apiculado. Inflorescência 2,1-12 cm compr., em racemo ou panícula, apical, ereta, base do pedúnculo envolvida por brácteas de ca. $1 \mathrm{~cm}$ compr.; brácteas florais membranáceas, $0,4-0,8 \mathrm{~cm}$ compr., linear-triangulares a triangulares, cobrindo o pedicelo e parte da flor, não escondendo o eixo da inflorescência, ápice acuminado. Flores 3-18 por inflorescência; pedicelo + ovário 0,4-0,8 cm compr., base não vesicada; sépalas creme-esverdeadas, a dorsal 0,5-0,6x 0,1-0,2 cm, elíptica, côncava, ápice agudo, as laterais 0,5-0,65×0,25-0,3 cm, lanceoladas, subfalcadas, côncavas, ápice agudo; pétalas $0,5-0,6 \times 0,1 \mathrm{~cm}$, creme-esverdeadas, linear-elípticas, sinuosas, margem inteira, ápice arredondado; labelo 0,6-0,7×0,6-0,7 cm, creme-esverdeado, carnoso, conduplicado, inteiro, cordiforme, margem inteira, ápice agudo, calo ausente; ginostêmio ca. $0,3 \mathrm{~cm}$ compr. Fruto 1,1-1,5×0,6-0,9 cm, ovóide a elipsóide.

Material selecionado: BRASIL. Paraná: Arapoti, 24/X/1961, Hatschbach 8520 (HB, MBM, UPCB); Campo Largo, 18/XI/1961, Hatschbach 8809 (HB, MBM); Capão Grande, III/1904, Dusén s.n. (R35863); Jaguariaíva, 4/XII/1964, Hatschbach 11971 (HB); Palmeira, 28/XI/1986, Hatschbach 50831 (MBM); Palmeira, 26/XI/2003, Stancik 51 (UPCB); Piraí do Sul, 16/I/1965, Smith 14561 (HB); Ponta Grossa, 16/XI/1959, Leinig 158 (HB); Sengés, 7/X/1971, Hatschbach 27142 (HB); Ventania, 16/III/1961, Seidel 2-62 (HB).

Observações: ocorre na Venezuela e Brasil (MT, GO, MG, RJ, SP, PR). Coletada com flores entre setembro e março e em maio, e com frutos entre janeiro e novembro. No Paraná, ocorre como terrestre, comumente junto de Sphagnum, em barrancos bastante úmidos e/ou próximo a fontes de água, em Floresta Ombrófila Mista e Estepe. Epidendrum dendrobioides não é citado por Pabst \& Dungs (1975) para o Paraná, mas sim duas outras espécies afins, E. aquaticum
Lindl. e E. pseudavicula Kraenzl. As três são espécies muito próximas e apresentam características vegetativas e florais muito semelhantes. Analisando as descrições das mesmas em Cogniaux (1893-1896), constata-se que a diferença entre elas está baseada apenas no tamanho, o que pode ser considerado como simples variação dentro de uma mesma espécie. Optou-se por usar, neste trabalho, o nome E. dendrobioides Thunb., por ser o mais antigo. Esse grupo merece revisão, e provavelmente estes nomes devam ser considerados sinônimos.

6. Epidendrum densiflorum Hook., Bot. Mag. 67: t. 3791. 1840.

= Epidendrum compositum Vell., Fl. Flumin. 9: t. 39. 1860.

= Epidendrum noackii Cogn. in Mart., Fl. Bras. 3(6): 569. 1906.

= Epidendrum brachythyrsus Kraenzl., Kongl. Svenska Vetenskapsakad. Handl. 46: 59. 1911.

Fig. 6

Epífita ou terrestre, ereta. Caule 6-90 cm compr., simples, compresso, 0,3-0,8 cm larg., espessura constante; rizoma inconspícuo. Folhas 1,7-15,5×0,7-5,2 cm, dísticas, subcoriáceas a submembranáceas, lanceoladas a elípticas, planas, ápice agudo. Inflorescência 4,5-40 cm compr., em panícula, apical, ereta, base do pedúnculo envolvida por brácteas de 2,5-6 cm compr.; brácteas florais membranáceas, $0,3-1,5 \mathrm{~cm}$ compr., ovaladas, cobrindo a base do pedicelo, ápice acuminado. Flores 6-80 por inflorescência; pedicelo + ovário 1-3,8 cm compr., base não vesicada; sépalas verde-claras a alvacentas, a dorsal 1-1,9×0,2-0,45 cm, oblanceolada a obovada, levemente côncava, ápice agudo, as laterais $1-1,7 \times 0,3-0,45 \mathrm{~cm}$, lanceoladas a obovadas, levemente encurvadas, levemente côncavas, ápice agudo; pétalas $1-1,8 \times 0,05-0,2 \mathrm{~cm}$, verde-claras a alvacentas, linearoblanceoladas, margem inteira, ápice agudo; labelo 1-1,9x 0,7-1,2 cm, creme, carnoso, plano, trilobado a tetralobado, lobos laterais suborbiculares, margem inteira, lobo mediano, quando trilobado, rasamente obtriangular com os ângulos arredondados, e quando tetralobado, lobos medianos lineares, falcados, divaricados, margem inteira; calo creme constituído por duas saliências arredondadas ca. $0,1 \mathrm{~cm}$, distantes entre si, basais, e uma lamela alongada central, ca. $0,3 \mathrm{~cm}$, da base ao ápice do labelo; ginostêmio $0,6-1,1 \mathrm{~cm}$ compr. Fruto não observado.

Material selecionado: BRASIL. Paraná: Antonina, 30/XI/1965, Hatschbach 13191 (HB, MBM); Campina Grande do Sul, 21/V/1967, Hatschbach 16465 (HB, MBM, UPCB); Campo Mourão, 15/V/1967, de Haas 5308 (HB); Capão Grande, III/1904, Dusén 4175 (HB, R, RB); Chopinzinho, 26/V/1972, Hatschbach 29720 (HB, MBM); Foz do Iguaçu, 15/XII/1965, Hatschbach 13366 (MBM); Guaíra, 24/I/1967, Hatschbach 15867 (HB); Guaratuba, 19/VI/1963, Hatschbach 10112 (MBM); Ipiranga, 25/IV/1904, Dusén 4465 (R); Jundiaí do Sul, 14/VI/1999, Carneiro 693 (MBM); Laranjeiras do Sul, 20/III/1967, Lindeman 5040 (MBM); Londrina, 21/V/2001, Ferrarezi 18 (FUEL); Palmital, II/1954, 
Leinig 94 (HB); Paranaguá, 30/VI/1986, Britez 773 (MBM, UPCB); Piraquara, 15/IV/1949, Hatschbach 1427 (MBM); Pontal do Paraná, 15/V/2003, Stancik 22 (UPCB); Prudentópolis, 10/IV/2003, Goldenberg 580 (UPCB); São Jorge do Oeste, 10/VI/1968, Hatschbach 19349 (HB); Sapopema, 24/V/1997, Kinupp 544 (FUEL); Terra Boa, 18/V/1969, Hatschbach 21558 (HB, MBM, UPCB); Tibagi, 8/VI/1953, Hatschbach 3292 (HB).

Material adicional: BRASIL. Santa Catarina: Enseada de Brito, VIII/1946, Curris s.n. (RB57456).

Observações: ocorre na Colômbia, Venezuela, Costa Rica, Guiana Francesa, Equador e Brasil (PA, AM, RO, MT, BA, GO, MG, ES, RJ, SP, PR, SC, RS). Coletada com flores praticamente durante todo o ano. No Paraná ocorre como epífita e também como terrestre sobre detritos vegetais, em Floresta Ombrófila Densa de Terras Baixas, Submontana e Montana, Floresta Ombrófila Mista e Floresta Estacional Semidecidual. Espécie de grande porte para o gênero, forma grandes touceiras de caules que quase chegam a $1 \mathrm{~m}$ de altura, dos quais saem grandes panículas de flores verdeclaras a alvacentas, de consistência carnosa. As flores exalam forte perfume que pode ser sentido a alguns metros de distância. Todos os materiais de E. densiflorum analisados estavam identificados como E. paniculatum Ruiz \& Pav., binômio comumente citado como sinônimo. No entanto, de acordo com Dodson \& Dodson (1980), E. paniculatum é uma outra espécie, muito próxima de E. densiflorum, cuja distribuição é restrita ao Equador e ao Peru. Pabst \& Dungs (1975) também citam para o Paraná, outra espécie muito próxima desta: $E$. nutans Sw., descrita originalmente para a Jamaica. Acredita-se que as identificações de Pabst, assim como a citação de E. nutans para o Paraná, se devam a determinações equivocadas de exemplares de $E$. densiflorum, pois a única exsicata encontrada, determinada por Pabst como E. nutans [Curris s.n. (RB57456)], pertence, na verdade, a E. densiflorum.

7. Epidendrum denticulatum Barb. Rodr., Gen. Sp. Orchid. 2: 143.1881.

Fig. 7

Terrestre ou rupícola, ereta. Caule 30-60 cm compr., simples, cilíndrico, ca. 0,7 cm diâm., espessura constante; rizoma não observado. Folhas 4,9-12×1,1-2,9 cm, dísticas, coriáceas, ovadas a lanceoladas, planas, ápice arredondado. Inflorescência ca. $56 \mathrm{~cm}$ compr., em corimbo, apical, ereta, base do pedúnculo envolvida por brácteas de $3-5 \mathrm{~cm}$ compr.; brácteas florais membranáceas, $0,1-0,5 \mathrm{~cm}$ compr., lineartriangulares a triangulares, cobrindo a base do pedicelo, ápice acuminado. Flores 30-115 por inflorescência; pedicelo + ovário 1-3 cm compr., base não vesicada; sépalas lilases a róseas, a dorsal 0,8-1×0,25-0,3 cm, ovada, plana, ápice agudo, as laterais $0,8-1,1 \times \mathrm{ca} .0,4 \mathrm{~cm}$, obovadas, subfalcadas, ligeiramente côncavas, ápice agudo; pétalas 0,8-1,1× 0,25-0,4 cm, lilases a róseas, oblanceoladas, margem inteira, ápice agudo; labelo 0,9-1,3×0,7-0,9 cm, lilás a róseo, delgado, plano, trilobado, lobos laterais deltóides, margem denticulada, istmo pouco evidente, lobo mediano deltóide, margem denticulada, ápice levemente bifurcado, calo creme, constituído por duas protuberâncias ovóides, ca. $0,1 \mathrm{~cm}$, basais, e uma lamela longitudinal, ca. $0,2 \mathrm{~cm}$, central; ginostêmio ca. $0,3 \mathrm{~cm}$ compr. Fruto não observado.

Material examinado: BRASIL. Paraná: Guaíra, 6/II/1980, Buttura 425 (MBM); Jaguariaíva, VII/1996, Noschang et al. s.n. (UPCB27536); Jaguariaíva, 10/VII/2003, Stancik 35 (UPCB).

Material adicional: BRASIL. Minas Gerais: Tiradentes, 16/II/1987, fl., Valka-Alves 23 (HB).

Observações: ocorre no Brasil (PE, BA, MG, ES, RJ, SP, PR, SC, RS). Coletada com flores em fevereiro e julho. No Paraná ocorre como terrestre ou rupícola em paredão de arenito em locais ensolarados de Floresta Ombrófila Mista. Espécies próximas de $E$. denticulatum, como $E$. ansiferum Rchb. f. e E. secundum Jacq., podem ser separadas por características das flores. Epidendrum ansiferum possui flores vermelhas, enquanto $E$. denticulatum e $E$. secundum apresentam flores lilases a róseas, com labelo trilobado muito semelhantes entre si e podem ser separadas por detalhes da calosidade do labelo: E. denticulatum apresenta calo constituído por duas saliências ovóides basais, e uma lamela central, de coloração creme, enquanto $E$. secundum possui um calo inteiriço, central, variadamente lobulado, de cor alva e/ou amarela.

8. Epidendrum fulgens Brongn., Voy. Monde p.196: t. 43. 1834.

= Epidendrum mosenii Rchb. f., Gard. Chron. new ser. 14: 390. 1880.

=Epidendrum bradeanum Kraenzl., Ark. Bot. 14(10): 3. 1915. Fig. 8

Terrestre ou rupícola, ereta. Caule 30-150 cm compr., simples, cilíndrico, 0,5-0,8 cm diâm., espessura constante; rizoma curto. Folhas 2,6-9,3×0,7-2,4 cm, dísticas, coriáceas, elíptico-ovadas a linear-elípticas, planas, ápice agudo, arredondado ou emarginado. Inflorescência 16,5-42,8 cm compr., em corimbo, apical, ereta, base do pedúnculo envolvida por brácteas de ca. $6 \mathrm{~cm}$ compr.; brácteas florais membranáceas, $0,2-1,7 \times 0,1-0,2 \mathrm{~cm}$, linear-triangulares, cobrindo a base do pedicelo, ápice acuminado. Flores 10-70 por inflorescência, pedicelo + ovário 0,8-3,7 cm compr., base não vesicada; sépalas amarelas a vermelhas, a dorsal 1,1-1,5×0,4-0,6 cm, lanceolada a obovada, plana, ápice agudo a arredondado, as laterais 1-1,5×0,4-0,7 cm, lanceoladas a obovadas, subfalcadas, ligeiramente côncavas, ápice agudo a arredondado; pétalas 1-1,6×0,3-0,7 cm, amarelas a vermelhas, rômbicas a obovadas, margem inteira a esparsamente erosa, ápice agudo a arredondado; labelo 1,2-1,9×0,9-1,8 cm, amarelo a vermelho, delgado, plano, trilobado, lobos laterais suborbiculares, margem denticulada, istmo pouco evidente, lobo mediano retangular a deltóide, margem denticulada, ápice emarginado a profundamente emarginado, calo amarelo a vermelho, constituído por duas saliências ovóides, ca. $0,1 \mathrm{~cm}$, basais, e uma lamela, 
longitudinal, ca. $0,15 \mathrm{~cm}$, central; ginostêmio $0,9-1,2 \mathrm{~cm}$ compr. Fruto ca. 3,3×1 cm, elipsóide.

Material selecionado: BRASIL. Paraná: Guaraqueçaba, 19/I/1993, Prado 415 (UPCB); Guaratuba, X/1951, Frenzel s.n. (MBM4798); Guaratuba, 25/I/1961, Leinig 232 (HB); Matinhos, 28/VIII/1972, Hatschbach 30262 (MBM); Paranaguá, 27/XI/1970, Hatschbach 25654 (HB, MBM); Pontal do Paraná, 10/X/1965, Moreira Filho 338 (UPCB).

Observações: ocorre no Brasil (RJ, SP, PR, SC, RS). Coletada com flores e frutos durante praticamente todo o ano. No Paraná é bastante comum em formações pioneiras (Restingas), onde ocorre em solos arenosos em locais ensolarados nas bordas da mata, junto à praia. A morfologia de suas flores varia bastante, o que pode causar confusão com E. puniceoluteum F. Pinheiro \& F. Barros. As flores de E. fulgens variam desde o amarelo até o vermelho, que tende para o alaranjado, e possuem labelo trilobado, com lobos laterais suborbiculares, lobo mediano emarginado a profundamente emarginado de margens fimbriadas e istmo pouco evidente. Epidendrum puniceoluteum, por sua vez, apresenta flores predominantemente vermelho-purpúreas, tendendo para o bordô, e labelo com lobos laterais obtriangulares, lobo mediano bilobulado e istmo bastante evidente. Foram encontrados, porém, exemplares que apresentam características intermediárias entre elas, e que, por ocorrerem na mesma faixa de restinga, acredita-se que sejam híbridos naturais entre essas duas espécies.

9. Epidendrum geniculatum Barb. Rodr., Gen. Spec. Orchid. 2: 146.1881.

Fig. 9

Epífita, ereta. Caule ca. $28 \mathrm{~cm}$ compr., simples, compresso, ca. $0,6 \mathrm{~cm}$ larg., espessura constante; rizoma curto, ca. $1 \mathrm{~cm}$. Folhas 11,1-16,5×1,8-2,6 cm, dísticas, cartáceas, elípticas, planas, ápice agudo. Inflorescência 5-5,4 cm compr., em racemo, apical, ereta, base do pedúnculo envolvida por ca. 4 brácteas imbricadas de ca. $1 \mathrm{~cm}$ compr.; brácteas florais membranáceas, 0,8-1,5×0,3-0,4 cm, lanceoladas, cobrindo até a metade do pedicelo, ápice agudo. Flores 3-4 por inflorescência; pedicelo + ovário 1,5-2,3 cm compr., base não vesicada; sépalas creme, a dorsal ca. $1,2 \times 0,4 \mathrm{~cm}$, ovada, plana, ápice agudo a acuminado; sépalas laterais ca. $1,2 \times 0,4 \mathrm{~cm}$, ovadas, levemente encurvadas, côncavas, ápice acuminado; pétalas ca. $0,9 \times 0,2 \mathrm{~cm}$, creme, oblanceoladas, margem inteira, ápice agudo a acuminado; labelo ca. $1,1 \times 0,55 \mathrm{~cm}$, creme, delgado, plano, inteiro, deltóideespatulado, margem inteira, ápice mucronulado, calo creme, ca. $0,3 \times 0,2 \mathrm{~cm}$, inteiriço, trilobulado, central; ginostêmio $0,3 \mathrm{~cm}$ compr. Fruto ca. $2,2 \times 1,1 \mathrm{~cm}$, ovóide.

Material examinado: BRASIL. Paraná: Guaraqueçaba, IV/1968, Hatschbach 19011 (MBM).

Material adicional: BRASIL. Santa Catarina: Florianópolis, 18/III/1951, Rohr 2108 (HB); Palhoça, 7/VI/1956, Reitz 3260 (HB); Sertão da Lagoa, 23/VII/1950, Rohr s.n. (HB782).
Observações: ocorre no Brasil (ES, RJ, SP, PR, SC). Coletada com flores em abril e junho, e com frutos em março e julho. No Paraná é pouco comum, ocorrendo como epífita em Floresta Ombrófila Densa Submontana. Por seu caule, com poucas folhas localizadas mais na porção apical, pode ser confundida com E. henschenii Barb. Rodr., porém suas flores são bem diferentes. Epidendrum geniculatum possui flores carnosas de cor creme, com o labelo inteiro, deltóideespatulado, enquanto E. henschenii as possui membranáceas, verdes e com o labelo trilobado.

10. Epidendrum henschenii Barb. Rodr., Gen. Sp. Orchid 2: 147. 1881.

= Epidendrum brevicolle Kraenzl., Ark. Bot. 16(8): 20. 1921. Fig. 10

Epífita, ereta. Caule 30-48 cm compr., simples, compresso, 0,4-0,5 cm larg., espessura constante; rizoma curto, ca. $1 \mathrm{~cm}$. Folhas 5,8-13×0,9-2,2 cm, dísticas, cartáceas a submembranáceas, elípticas, planas, ápice agudo a arredondado. Inflorescência 2-6 cm compr., em racemo, apical, pendente, base do pedúnculo envolvida por ca. 4 brácteas imbricadas com ca. $1,5 \mathrm{~cm}$ compr.; brácteas florais membranáceas, $0,2-0,5 \times 0,15-0,2 \mathrm{~cm}$, lanceoladas, cobrindo a base do pedicelo, ápice agudo. Flores 6-8 por inflorescência; pedicelo + ovário 1,1-1,5 cm compr., base não vesicada; sépalas verdes, a dorsal ca. $1 \times 0,25 \mathrm{~cm}$, oblanceolada, levemente côncava, ápice agudo, as laterais ca. $1 \times 0,3 \mathrm{~cm}$, oblanceoladas, subfalcadas, levemente côncavas, ápice agudo; pétalas ca. $0,9 \times 0,1 \mathrm{~cm}$, verdes, espatuladas, margem inteira, ápice arredondado; labelo ca. $1 \times 0,9 \mathrm{~cm}$, verde, delgado, plano, trilobado, lobos laterais orbiculares, margem inteira, lobo mediano suborbicular, margem inteira, ápice fendido, calo verde, constituído por duas saliências ovóides, ca. $0,1 \mathrm{~cm}$, distantes entre si, basais; ginostêmio ca. $0,6 \mathrm{~cm}$ compr. Fruto não observado.

Material adicional: BRASIL. Santa Catarina: Corupá, 1/IV/1974, Seidel 1098 (HB); s. localidade, VII/1953, s. col., s.n. (HB2117). São Paulo: Angatuba, II/1966, Emmerich 2840 (R).

Observações: ocorre no Brasil (MG, SP, PR, SC). Coletada com flores em abril e julho, em Floresta Ombrófila Densa Submontana. Espécie próxima de E. geniculatum Barb. Rodr., da qual se distingue pelas características florais comentadas em E. geniculatum. Pabst \& Dungs (1975) citam E. henschenii para o Paraná, porém não foram encontrados espécimens nos herbários visitados, e nem nos ambientes visitados nas expedições de coleta. A descrição apresentada neste trabalho foi baseada em material proveniente de Santa Catarina, município de Corupá, região muito próxima da divisa com o estado do Paraná. Devido a essa proximidade, acredita-se que E. henschenii realmente ocorra no estado.

11. Epidendrum latilabre Lindl., Edwards's Bot. Reg. 27(misc.): 77. 1841.

$=$ Epidendrum radiatum Hoffmanns., Verz. Orch. p.24. 1842

(non E. radiatum Lindl., 1841). 

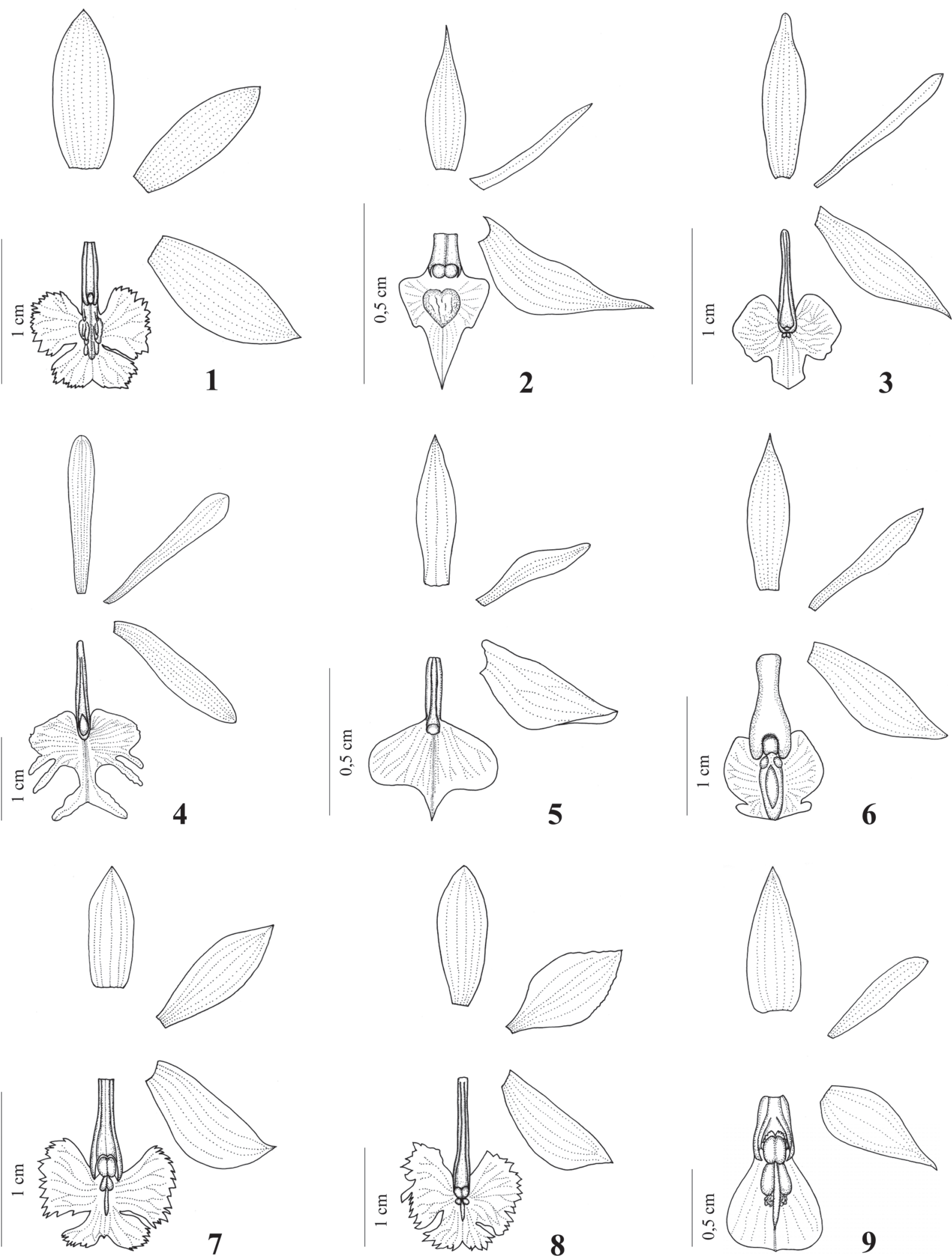

Figuras 1-9. Peças florais das espécies de Epidendrum no Paraná. 1. Epidendrum ansiferum Rchb. f. (Lindeman 2366). 2. Epidendrum armeniacum Lindl. (Hatschbach 13199). 3. Epidendrum caldense Barb. Rodr. (Hatschbach 3252). 4. Epidendrum cristatum Ruiz \& Pav. (Hatschbach 8703). 5. Epidendrum dendrobioides Thunb. (Hatschbach 50831). 6. Epidendrum densiflorum Hook. (Goldenberg 580). 7. Epidendrum denticulatum Barb. Rodr. (Valka-Alves 23). 8. Epidendrum fulgens Brongn. (Frenzel s.n. MBM4798). 9. Epidendrum geniculatum Barb. Rodr. (Reitz. 3260). 
= Epidendrum arachnoideum Barb. Rodr., Gen. Sp. Orchid 1:60. 1877.

= Epidendrum uniflorum Barb. Rodr., Gen. Sp. Orchid. 1: 61. 1877.

= Epidendrum althausenii A.D. Hawkes, Orquídea (Rio de Janeiro) 18: 168. 1957.

Fig. 11

Epífita, ereta. Caule 2,8-19 cm compr., simples, compresso, 0,4-0,8 cm larg., estreito na base, espessando para o ápice; rizoma curto, ca. $0,8 \mathrm{~cm}$. Folhas 1,6-11,8×0,6-3,7 cm, dísticas, coriáceas, estreitamente elípticas a elípticas, planas, ápice arredondado a retuso. Inflorescência ca. $1 \mathrm{~cm}$ compr., em racemo, apical, ereta, base do pedúnculo envolvida por brácteas de ca. $1 \mathrm{~cm}$ compr.; brácteas florais membranáceas, ca. $0,5 \mathrm{~cm}$ compr., linear-triangulares a triangulares, cobrindo a base do pedicelo, ápice acuminado. Flores 1-5 por inflorescência; pedicelo + ovário 1,5-5,5 cm compr., base não vesicada; sépalas verdes, a dorsal 0,9-3,2×0,2-0,5 cm, elíptica, plana, ápice agudo, as laterais 1,2-3,1×0,2-0,7 cm, elípticas, subfalcadas, planas, ápice agudo; pétalas 1,5-3× 0,1-0,5 cm, verdes, linear-oblanceoladas a oblanceoladas, margem inteira, ápice agudo; labelo 1,6-3,2×2-4 cm, verde, delgado, trilobado, âmbito subreniforme, lobos laterais obliquamente elípticos, margem inteira, lobo mediano suborbicular, refletido, margem inteira, ápice fendido; calo ausente; ginostêmio 0,9-2,3 cm compr. Fruto não observado.

Material selecionado: BRASIL. Paraná: Antonina, 28/IV/1976, Hatschbach 38579 (MBM); Guaraqueçaba, 10/IV/1968, Hatschbach 19002 (MBM); Guaratuba, V/1958, Leinig 31 (HB); Morretes, 6/IV/1904, Dusén 4376 (R); Paranaguá, VII/1949, Hertel s.n. (MBM 255663); Pontal do Paraná, 8/V/2003, Stancik 14 (UPCB); Rio Branco do Sul, 8/V/1968, Hatschbach 19214 (MBM).

Observações: ocorre no Brasil (PA, AM, PE, MG, ES, RJ, SP, PR, SC, RS). Coletada com flores em fevereiro e entre abril e julho. No Paraná é bastante freqüente em Floresta Ombrófila Densa de Terras Baixas e Submontana, mas também ocorre em Floresta Ombrófila Mista. Suas características vegetativas são facilmente confundidas com as de E. pseudodifforme Hoehne \& Schltr., porém suas folhas são maiores e mais robustas (1,6-11,8×0,6-3,7 cm), assim como seus caules, que são estreitos na base e mais largos no ápice, ao contrário de $E$. pseudodifforme cujo caule tem a mesma espessura desde a base até o ápice. Além disso, E. latilabre floresce predominantemente em abril e maio, e E. pseudodifforme, em janeiro.

12. Epidendrum nocturnum Jacq., Enum. Syst. Pl. p. 29. 1760.

= Epidendrum longicolle Lindl., Edwards's Bot. Reg. 24 (misc.): 34. 1838.

Fig. 12

Epífita, ereta. Caule 8-44,5 cm compr., simples, compresso, 0,4-0,5 cm larg., espessura constante; rizoma curto, ca. 0,7 cm. Folhas 5,3-12,3×0,9-3,2 cm, dísticas, cartáceas, elípticas a lanceoladas, planas, ápice arredondado. Inflorescência ca. $1 \mathrm{~cm}$ compr., em racemo, apical, ereta, base do pedúnculo envolvida por brácteas de ca. $1 \mathrm{~cm}$ compr.; brácteas florais membranáceas, ca. $0,5 \mathrm{~cm}$ compr., linear-triangulares a triangulares, cobrindo a base do pedicelo, ápice acuminado. Flores 1-6 por inflorescência; pedicelo 4-8 cm compr., base não vesicada; sépalas creme-esverdeadas, a dorsal 2,5-3,8× 0,2-0,3 cm, elíptica, plana, ápice agudo, as laterais 2,1-3,7× 0,35-0,4 cm, lanceoladas, subfalcadas, ligeiramente côncavas, ápice agudo; pétalas 2,3-3,6×0,1-0,2 cm, cremeesverdeadas, lineares a estreitamente elípticas, margem inteira, ápice agudo; labelo 2,1-3,5×1,3-1,7 cm, alvo, delgado, plano, trilobado, lobos laterais suborbiculares, margem inteira, lobo mediano linear-triangular, ápice agudo, calo amarelo, constituído por duas lamelas longitudinais, próximas entre si, ca. $0,15 \mathrm{~cm}$, basais; ginostêmio 1,1-1,3 cm compr. Fruto ca. $0,5 \times 2,5 \mathrm{~cm}$, fusiforme.

Material examinado: BRASIL. Paraná: Matinhos, 22/V/2003, Stancik 26 (UPCB); Morretes, 4/III/2003, Stancik 6(UPCB); Paranaguá, s.d., Hatschbach 2630 (MBM); Pontal do Paraná, 8/V/2003, Stancik 17 (UPCB).

Observações: ocorre desde a Flórida até a América do Sul, no Brasil (AP, PA, AM, AC, PE, MT, GO, MG, ES, SP, PR, $\mathrm{SC}, \mathrm{RS})$. Coletada com flores em janeiro e com frutos entre março e maio. No Paraná ocorre como epífita em locais sombreados da Restinga, em Floresta Ombrófila Densa Submontana e de Terras Baixas. Geralmente de pequeno porte, cresce em pequenas touceiras com 1-5 caules, embora alguns exemplares possam apresentar vários caules de até 44,5 cm de comprimento. Uma particularidade dessa espécie, observada em campo e em cultivo, é que as flores são, quase sempre, cleistogâmicas. Todas as coletas realizadas apresentaram frutos com o botão floral ainda fechado.

13. Epidendrum paranaense Barb. Rodr., Gen. Sp. Orchid. 2: 139.1881.

= Epidendrum imbricatum Lindl., Gen. Sp. Orchid. Pl. p.110. 1831 (non Lam. 1793)

= Epidendrum biflorum Cogn., Bull. Herb. Boissier 2(2): 337, figs. 1-3. 1902.

= Epidendrum boissierianum Schltr., Beih. Bot. Centralbl. 36(2): 459. 1918.

Fig. 13

Epífita, pendente. Caule 14-80 cm compr., ramificado, cilíndrico, 0,5-1 cm diâm., espessura constante; rizoma longo, ca. 4 cm, rígido. Folhas 4,5-15,5×1,1-3 cm, dísticas, coriáceas, lanceoladas a estreitamente elípticas, planas, ápice arredondado a agudo. Inflorescência 3,5-7 cm compr., em racemo, apical, ereta, base do pedúnculo envolvida por ca. 2 brácteas imbricadas de 1-2,5 cm compr.; brácteas florais coriáceas, 2-2,5 cm compr., lanceoladas, cobrindo o pedicelo e parte da flor, escondendo o eixo da inflorescência, ápice agudo. Flores 5-7 por inflorescência; pedicelo + ovário 1,6-2,1 cm compr., base não vesicada; sépalas alvacentas, a dorsal 1,1-1,4×0,3-0,4 cm, ovada, côncava, ápice agudo, as laterais $1,1-1,4 \times 0,3-0,5 \mathrm{~cm}$, lanceolado-ovadas, levemente 
encurvadas, planas, ápice agudo; pétalas 1-1,3×0,1-0,3 cm, alvacentas, lanceoladas, margem inteira, ápice agudo; labelo 1-1,4×0,4-0,7 cm, alvacento, carnoso, plano, inteiro, cordiforme, margem inteira, ápice agudo, calo alvacento, constituído por duas saliências ovóides, próximas entre si, ca. $0,1 \mathrm{~cm}$, basais; ginostêmio 0,4-0,6 cm compr. Fruto 2-2,2×ca. 1,1 cm, globóide.

Material selecionado: BRASIL. Paraná: Antonina, 20/I/1966, Hatschbach 13582 (HB, MBM); Morretes, 4/I/1966, Hatschbach 13444 (MBM); Paranaguá, 24/VI/2003, Stancik 28(UPCB).

Observações: ocorre no Brasil (MG, ES, RJ, SP, PR, SC). Coletada com flores em janeiro, fevereiro e setembro, e com frutos em janeiro e junho. No Paraná é representada por epífitas de grande porte, geralmente nas regiões mais altas das árvores, acima de $3 \mathrm{~m}$ de altura, em locais sombreados de Floresta Ombrófila Densa de Terras Baixas e Montana. Em comparação com as outras espécies do estado com caule pendente, como E. ramosum Jacq., E. saximontanum Pabst, E. strobiliferum Rchb. f. e E. vesicatum Lindl., E. paranaense é a espécie que apresenta maior porte, com caules que chegam a $80 \mathrm{~cm}$ de comprimento e flores com sépalas e pétalas maiores que $1 \mathrm{~cm}$. E. vesicatum possui grandes folhas glaucas, conchiformes e imbricadas, que cobrem o caule. E. ramosum apresenta caule estreito, densamente ramificado, com folhas estreitas, de no máximo $9,4 \mathrm{~cm}$ de comprimento. Já E. strobiliferum e E. saximontanum apresentam porte muito reduzido, a primeira com caules curtos entre 2 e $12 \mathrm{~cm}$ de comprimento, com folhas que não chegam a $3 \mathrm{~cm}$ de comprimento, enquanto a segunda é a que apresenta o menor tamanho: caules de até $10 \mathrm{~cm}$ de comprimento e folhas, conduplicadas e recurvas, de no máximo $1,2 \mathrm{~cm}$ de comprimento.

14. Epidendrum proligerum Barb. Rodr., Gen. Sp. Orchid. 1:61. 1877.

Fig. 14

Epífita, ereta. Caule 1,3-16,5 cm compr., ramificado, cilíndrico, 0,2-0,4 cm diâm., espessura constante; rizoma curto, ca. $1 \mathrm{~cm}$. Folhas 2,1-10,8×0,5-2 cm, dísticas, membranáceas, elípticas, planas, ápice agudo a acuminado. Inflorescência 2,5-3,5 cm compr., em racemo, apical, ereta, base do pedúnculo não envolvida por brácteas; brácteas florais membranáceas, ca. 0,3 cm compr., triangulares, cobrindo até a metade do pedicelo, ápice acuminado. Flores 4-12 por inflorescência; pedicelo + ovário ca. $0,5 \mathrm{~cm}$ compr., base não vesicada; sépalas verdes, a dorsal 1,1-1,2× 0,2-0,3 cm, oblanceolada, ligeiramente côncava, ápice agudo a acuminado, as laterais 1,1-1,3×ca. 0,3 cm, elípticas, subfalcadas, ligeiramente côncavas, ápice acuminado; pétalas 1-1,2×ca. $0,15 \mathrm{~cm}$, verdes, linear-oblanceoladas, margem inteira, ápice agudo; labelo 1-1,2×1-1,3 cm, verde, delgado, plano, trilobado, lobos laterais orbiculares, margem inteira, lobo mediano suborbicular, margem inteira, ápice fendido, calo verde, constituído por duas saliências ovóides, distantes entre si, ca. $0,1 \mathrm{~cm}$, basais; ginostêmio $0,7-0,8 \mathrm{~cm}$ compr. Fruto não observado.
Material selecionado: BRASIL. Paraná: Bocaiúva do Sul, 14/I/1969, Hatschbach 20710 (MBM); Guaratuba, 10/II/1960, Leinig 184 (HB); Guaratuba, 22/VI/1952, Hatschbach 2667 (HB, MBM); Ipiranga, 8/II/1904, Dusén 3786 (R); Morretes, 3/III/1974, Leinig 555 (HB); Piraquara, 23/II/1952, Hatschbach 3144 (HB, MBM).

Material adicional: BRASIL. Rio de Janeiro: Rio de Janeiro, 30/V/1954, Pabst 2454 (HB); Santa Maria Madalena, 20/XII/1988, Martinelli 13219 et al. (RB); Teresópolis, 26/IX/1969, Brade 9439 (R). Santa Catarina: Itajaí, 21/VI/1956, Reitz 3316 et al. (HB); Palhoça, 18/V/1971, Klein 9417 et al. (HB). São Paulo: Paranapiacaba, 30/V/1972, Handro 2207 (HB).

Observações: ocorre no Brasil (MG, RJ, SP, PR, SC). Coletada com flores entre dezembro e junho, e setembro. No Paraná ocorre como epífita em Floresta Ombrófila Densa de Terras Baixas, Submontana e Montana, e em Floresta Ombrófila Mista. Outras espécies afins são citadas por Pabst \& Dungs (1975), para o estado do Paraná: E. ecostatum Pabst, E. obergii Hawkes e E. ochrochlorum Barb. Rodr. Todas são muito semelhantes a $E$. proligerum e entre si, sendo a principal diferença entre elas o formato do labelo, o que pode ser visto nas ilustrações de Pabst \& Dungs (1975) para essas espécies. Analisando as exsicatas atribuídas a essas espécies nos herbários, observou-se que todos os materiais identificados como E. ochrochlorum (Leinig 184 e 555; Hatschbach 3144 e 2667; Hatschbach 20710), E. obergii (Klein 9417), E. ecostatum (Handro 2207; Klein 10165; Dusén 3786) e E. proligerum (Reitz 3316; Pabst 2454) correspondiam à mesma espécie. Em análise das descrições dessas espécies, decidiu-se tratá-las, neste trabalho, com o nome E. proligerum, pois E. ochrochlorum apresenta flores com o dobro do tamanho dos espécimes analisados, e E. obergii, assim como E. ecostatum, possuem labelo inteiro. Este é outro grupo dentro do gênero Epidendrum que está necessitando de revisão, a qual poderia resultar em várias sinonimizações.

15. Epidendrum pseudodifforme Hoehne \& Schltr., Arq.

Bot. Estado Sao Paulo 1: 242. 1926.

Fig. 15

Epífita, ereta ou flexuosa. Caule ca. 11,4 cm compr., simples, compresso, 0,3-0,7 cm larg., espessura constante; rizoma inconspícuo. Folhas 3-5×1,3-2,1 cm, dísticas, coriáceas, oblongas, planas, ápice retuso. Inflorescência ca. $1 \mathrm{~cm}$ compr., em racemo, apical, ereta, base do pedúnculo envolvida por brácteas de ca. $1 \mathrm{~cm}$ compr.; brácteas florais membranáceas, ca. 0,5 cm compr., linear-triangulares a triangulares, cobrindo a base do pedicelo, ápice acuminado. Flores ca. 10 por inflorescência; pedicelo + ovário 2,4-2,9 cm compr., base não vesicada; sépalas verdes, a dorsal ca. 1,2×0,4 cm, elíptica, plana, ápice agudo, as laterais ca. $1,2 \times 0,5 \mathrm{~cm}$, rômbicas, planas, ápice agudo a acuminado; pétalas ca. $1 \times 0,2 \mathrm{~cm}$, verdes, linear-obovadas, margem inteira, ápice agudo a arredondado; labelo ca. 1,1×1,2 cm, verde, delgado, plano, trilobado, lobos laterais orbiculares, 
margem inteira, lobo mediano suborbicular, sub-patente, margem inteira, ápice fendido, calo verde, constituído de duas saliências ovóides, distantes entre si, ca. $0,1 \mathrm{~cm}$, basais; ginostêmio ca. $0,8 \mathrm{~cm}$ compr. Fruto ca. $2 \times 1 \mathrm{~cm}$, globóide.

Material examinado: BRASIL. Paraná: Morretes, 27/I/1987, Silva 295 (MBM); Morretes, 4/III/2003, Stancik 7 (UPCB); Morretes, 12/VI/2003, Stancik 27 (UPCB); Paranaguá, 15/I/1970, Hatschbach 23336 (MBM); Paranaguá, 15/V/2003, Stancik 19 (UPCB).

Observações: ocorre nas Américas Central e do Sul, incluindo o Brasil (AM, AP, PA, MA, PE, MG, RJ, SP, PR, SC, RS). Coletada com flores em janeiro e com frutos em março, maio e junho. No Paraná ocorre como epífita em formações pioneiras e Floresta Ombrófila Densa Submontana. Algumas de suas características vegetativas, como caule ereto ou flexuoso, compresso e coberto por bainhas das folhas, são compartilhadas com E. latilabre Lindl., espécie próxima. Para maiores detalhes sobre a diferenciação entre as duas, ver comentários sob E. latilabre. Epidendrum pseudodifforme é tratada por Pabst \& Dungs (1975) como E. difforme Jacq. De acordo com Saldaña \& Hágsater (1996), que realizaram um estudo sobre esse grupo de espécies, a distribuição de E. difforme é restrita às ilhas do mar do Caribe, em florestas úmidas de 300 a 1.000 m s.n.m. No entanto, esse nome vem sendo utilizado de forma generalizada para designar várias espécies semelhantes de diversas regiões do Neotrópico.

16. Epidendrum puniceoluteum F. Pinheiro \& F. Barros, Hoehnea 33(2): 248. 2006.

Fig. 16

Terrestre ou rupícola, ereta. Caule 69-100 cm compr., simples, cilíndrico, ca. $1 \mathrm{~cm}$ diâm.; rizoma não observado. Folhas 4,9-8,6×1,8-3,2 cm, dísticas, coriáceas, ovadas, planas, ápice arredondado. Inflorescência $30-50 \mathrm{~cm}$ compr., em corimbo, apical, ereta, base do pedúnculo envolvida por brácteas de ca. $6,5 \mathrm{~cm}$ compr.; brácteas florais membranáceas, ca. $1 \times 0,2 \mathrm{~cm}$, linear-triangulares, cobrindo a base do pedicelo, ápice acuminado. Flores ca. 40 por inflorescência,; pedicelo + ovário ca. $3 \mathrm{~cm}$ compr., base não vesicada; sépalas vermelho-purpúreas, a dorsal ca. $1,4 \times 0,5 \mathrm{~cm}$, obovada, plana, ápice agudo, as laterais ca. 1,2×0,6 cm, obovadas, subfalcadas, ligeiramente côncavas, ápice agudo; pétalas ca. $1,3 \times 0,5 \mathrm{~cm}$, vermelho-purpúreas, estreitamente rômbicas, margem inteira, ápice agudo; labelo ca. $1,2 \times 1,1 \mathrm{~cm}$, vermelhopurpúreo, delgado, plano, trilobado, lobos laterais obtriangulares, margem denticulada, istmo bastante evidente, lobo mediano obtriangular, bilobulado, margem denticulada, ápice denticulado, calo amarelo, constituído de duas saliências ovóides, ca. $0,1 \mathrm{~cm}$, basais e uma lamela, longitudinal, ca. $0,2 \mathrm{~cm}$, central; ginostêmio ca. $0,9 \mathrm{~cm}$ compr. Fruto ca. $4 \times 1,1 \mathrm{~cm}$, fusiforme.

Material selecionado: BRASIL. Paraná: Guaratuba, 15/I/1970, Leinig 435 (HB); Matinhos, 31/I/1974, Kummrow 262 (HB, MBM); Paranaguá, 20/I/1996, Ribas 1051 (MBM); Pontal do Paraná, 23/IV/1967, Hatschbach 16386 (HB, MBM); Pontal do Paraná, 26/I/2004, Stancik 53 (UPCB).
Observações: ocorre no Brasil (RJ, SP, PR, SC, RS). Coletada com flores entre novembro e fevereiro e em abril, e com frutos em janeiro, fevereiro e abril. No Paraná ocorre como terrestre em locais ensolarados, em formações pioneiras (Restinga). Um pouco menos freqüente que E. fulgens Brongn., E. puniceoluteum apresenta características vegetativas muito semelhantes a ela. Ambas podem ser facilmente confundidas e a diferenciação entre elas pode ser vista nos comentários sob E. fulgens. Esta espécie tem sido costumeiramente identificada como E. purpureum Barb. Rodr. (p. ex., em Pabst \& Dungs 1975), mas o verdadeiro E. purpureum é um híbrido natural entre E. myrmecophorum Barb. Rodr. (= E. huebneri Schltr.) e E. denticulatum Barb.Rodr. e ocorre em restinga no estado do Rio de Janeiro, tendo, recentemente sido descrita com o nome Epidendrum xormindoi F.E. Miranda.

17. Epidendrum ramosum Jacq., Enum. Syst. Pl. p. 29. 1760. = Epidendrum rigidum Lodd., Bot. Cab. 16(10): tab. 1600.

1830. (non Jacq., 1760)

= Epidendrum sellowii Reichb. f., Linnaea 22: 839. 1849.

= Epidendrum flexicaule Schltr., Beih. Bot. Centralbl. 36(2): 403. 1918.

= Epidendrum modestiflorum Schltr., Repert. Spec. Nov. Regni Veg. Beih. 19: 213. 1923.

= Epidendrum pedale Schltr., Repert. Spec. Nov. Regni Veg. 23: 50. 1926.

Fig. 17

Epífita, pendente. Caule 2-63 cm compr., densamente ramificado, cilíndrico, 0,2-0,5 cm diâm., espessura constante; rizoma longo, ca. $4 \mathrm{~cm}$. Folhas 1,2-9,4×0,3-1,1 cm, dísticas, coriáceas, estreitamente oblongas, planas, ápice arredondado a retuso. Inflorescência 2-5,5 cm compr., em racemo, apical, pendente, base do pedúnculo envolvida por bráctea de 0,9-1,2 cm compr.; brácteas florais membranáceas, $0,5-1 \mathrm{~cm}$ compr., linear-lanceoladas, cobrindo o pedicelo e parte da flor, não escondendo o eixo da inflorescência, ápice agudo. Flores 2-7 por inflorescência; pedicelo + ovário 0,4-1 cm compr., base não vesicada; sépalas creme-esverdeadas a verdes, a dorsal $0,5-0,8 \times 0,1-0,2 \mathrm{~cm}$, ovada, plana, ápice agudo, as laterais $0,6-0,8 \times 0,12-0,25 \mathrm{~cm}$, ovadas, subfalcadas, planas, ápice agudo; pétalas $0,6-0,8 \times 0,05-0,1 \mathrm{~cm}$, cremeesverdeadas a verdes, lineares, margem inteira, ápice agudo; labelo 0,6-0,9×0,2-0,4 cm, creme-esverdeado, membranáceo, plano, inteiro, cordiforme, margem inteira, ápice agudo, calo creme-esverdeado, constituído por duas saliências ovóides, próximas entre si, ca. $0,08 \mathrm{~cm}$, basais e uma lamela longitudinal, ca. $0,08 \mathrm{~cm}$, central; ginostêmio $0,4-1 \mathrm{~cm}$ compr. Fruto 0,9×0,6 cm, globóide.

Material selecionado: BRASIL. Paraná: Antonina, 15/VIII/2003, Stancik 44 (UPCB); Curitiba, I/1943, Guimarães s.n. (RB48257); Guaraqueçaba, 3/II/2000, Gatti 617 (SP, UPCB); Guaratuba, 27/VII/1966, Hatschbach 14516 (HB, MBM); Morretes, 4/III/2003, Stancik 9 (UPCB); Paranaguá, 29/V/1965, Hatschbach 14388 (MBM); Pontal do Paraná, 1/II/1966, Hatschbach 13656 (MBM). 
Observações: ocorre na Guiana Francesa e Brasil (AM, PE, MG, RJ, SP, PR, SC, RS). Coletada com flores entre setembro e maio e em julho, e com frutos em maio. No Paraná é epífita comum no estrato inferior da floresta, em locais sombreados de Floresta Ombrófila Densa de Terras Baixas, Submontana e Montana, e Floresta Ombrófila Mista. Pabst \& Dungs (1975) também indicam a ocorrência de E. pedale Schltr. para o estado, porém nenhuma exsicata correspondente foi encontrada. Na descrição original de $E$. pedale, o autor comenta de que essa espécie seria semelhante a $E$. ramosum, diferindo pelas hastes secundárias do caule fortes e mais grossas, folhas mais obtusas e mais longas e segmentos florais maiores. Foi considerado, neste trabalho, que E. pedale deve ser apenas uma variação morfológica de E. ramosum, e todos os materiais analisados foram tratados como E. ramosum.

18. Epidendrum rigidum Jacq., Enum. Syst. Pl. p. 29. 1760. Fig. 18

Epífita, ereta. Caule 3,5-16 cm compr., simples, compresso, 0,3-0,6 cm larg., espessura constante; rizoma curto a longo 1-3 cm. Folhas $1,5-6,8 \times 0,5-2,2 \mathrm{~cm}$, dísticas, coriáceas, elípticas, planas, ápice arredondado. Inflorescência 3,5-11 cm compr., em racemo, apical, ereta, base envolvida por brácteas de 3-6 cm compr.; brácteas florais coriáceas, 1,2-2 cm compr., ovaladas a lanceoladas, cobrindo o pedicelo e parte da flor, ápice acuminado. Flores 3-9 por inflorescência; pedicelo + ovário $0,7-1,8 \mathrm{~cm}$ compr., base não vesicada; sépalas verdes, a dorsal 0,6-0,8 $\times 0,2-0,3 \mathrm{~cm}$, ovada, côncava, ápice agudo, as laterais $0,6-0,8 \times 0,3-0,4 \mathrm{~cm}$, ovadas, subfalcadas, levemente côncavas, ápice agudo; pétalas 0,5-0,8×ca. $1 \mathrm{~cm}$, verdes, linear-lanceoladas, margem inteira, ápice agudo; labelo $0,6-0,8 \times 0,3-0,4 \mathrm{~cm}$, verde, carnoso, plano, inteiro, cordiforme, margem inteira, ápice agudo, calo verde, constituído por duas saliências ovóides, próximas entre si, ca. $0,1 \mathrm{~cm}$, basais e uma lamela longitudinal, ca. $0,15 \mathrm{~cm}$, central; ginostêmio 0,3-0,4 cm compr. Fruto ca. 1,7×0,8-0,9 cm, ovóide.

Material selecionado: BRASIL. Paraná: Antonina, 15/VIII/2003, Stancik 42 (UPCB); Guaraqueçaba, 19/III/1977, Hatschbach 39798 (MBM); Guaratuba, 18/VI/1963, Hatschbach 10122 (MBM); Jataizinho, 16/II/2001, Ferrarezi 28 (FUEL); Laranjeiras do Sul, 18/IV/1970, Hatschbach 24173 (HB, MBM); Matinhos, 20/IV/1981, Kummrow 1521 (MBM); Morretes, 4/III/2003, Stancik 5(UPCB); Paranaguá, 18/II/1976, Hatschbach 38097 (MBM); Pontal do Paraná, 8/V/2003, Stancik 16 (UPCB); Ribeirão do Pinhal, 10/II/2000, Carneiro 881 (MBM).

Observações: ocorre na América Central, Venezuela, Guiana Francesa, Bolívia e Brasil (RR, PA, AM, CE, PE, BA, MG, ES, RJ, SP, PR, SC, RS). Coletada com flores entre janeiro e julho e em novembro, e com frutos em fevereiro, entre abril e julho e em novembro. No Paraná é bastante comum como epífita em locais sombreados de Restinga e matas pluviais, em Floresta Ombrófila Densa de Terras Baixas, Submontana e Montana, Floresta Ombrófila Mista e Floresta Estacional Semidecidual. Freqüentemente E. rigidum é confundido com
E. ramosum Jacq., no entanto E. rigidum apresenta caule simples e ereto e flores carnosas, enquanto E. ramosum apresenta caule densamente ramificado e pendente e flores membranáceas.

\section{Epidendrum saximontanum Pabst, Anais $15^{\circ}$ Congr.} Soc. Bot. Brasil p.112. 1967.

Fig. 19-20

Epífita, pendente. Caule 5-10 cm compr., ramificado, compresso, ca. 0,2 cm larg., espessura constante; rizoma incospícuo. Folhas 0,6-1,2×0,2-0,45 cm, dísticas, coriáceas, elípticas, recurvadas, conduplicadas, ápice agudo a arredondado. Inflorescência 0,7-1 cm compr., em racemo, apical, ereta, base do pedúnculo envolvida por 2 brácteas de ca. $0,3 \mathrm{~cm}$ compr.; brácteas florais membranáceas, ca. $0,4 \mathrm{~cm}$ compr., ovadas, cobrindo o pedicelo e parte da flor, escondendo o eixo da inflorescência, ápice agudo a arredondado. Flores 3-4 por inflorescência; pedicelo + ovário ca. $0,2 \mathrm{~cm}$ compr., com base vesicada; sépalas verdes, a dorsal ca. $0,25 \times 0,15 \mathrm{~cm}$, ovada, plana, ápice agudo, as laterais ca. $0,3 \times 0,15 \mathrm{~cm}$, ovadas, subfalcadas, planas, ápice agudo; pétalas $0,2 \times 0,01 \mathrm{~cm}$, verdes, lineares, margem inteira, ápice agudo a arredondado; labelo ca. $0,3 \times 0,15 \mathrm{~cm}$, verde, membranáceo, plano, inteiro, lanceolado, margem inteira, ápice agudo; calo verde, constituído por duas saliências ovóides, ca. $0,01 \mathrm{~cm}$, próximas entre si, basais; ginostêmio ca. $0,1 \mathrm{~cm}$ compr. Fruto ca. $0,5 \times 0,4 \mathrm{~cm}$, globóide.

Material examinado: BRASIL. Paraná: Pontal do Paraná, VII/2003, Stancik 32 (UPCB); Pontal do Paraná, 26/I/2004, Stancik 54 (UPCB), Pontal do Paraná, 2/X/2005, Stancik 57 (MBM).

Observações: ocorre no Brasil (SP e PR). Coletada com frutos em janeiro e flores em outubro. No Paraná ocorre como epífita em local sombreado em Floresta Ombrófila Densa de Terras Baixas. Epidendrum saximontanum foi descrito para o estado de São Paulo e está sendo registrada pela primeira vez no Paraná. É uma espécie muito próxima de E. strobiliferum Rchb. f., E. ramosum Jacq. e E. paranaense Barb. Rodr. ("Aliança E. ramosum"). Apresenta características semelhantes a essas espécies, como grandes brácteas florais que cobrem o pedicelo e parte da flor, porém é uma planta de porte reduzido. Dentre as espécies de Epidendrum ocorrentes no estado do Paraná, é a que apresenta as menores flores, com aproximadamente $0,4 \mathrm{~cm}$ de diâmetro. Para maiores informações sobre a diferenciação entre essas espécies, ver comentários sob E. paranaense.

20. Epidendrum secundum Jacq., Enum. Syst. Pl. p. 29. 1760. = Epidendrum elongatum Jacq., Collectanea 3: 260. 1789.

= Epidendrum corymbosum Ruiz \& Pav., Syst. Veg. Fl. Peruv. Chil.: 246. 1798.

$=$ Epidendrum longihastatum Barb.Rodr., Gen. Spec. Orchid. 1:59. 1877.

$=$ Epidendrum versicolor Hoehne \& Schltr., Arq. Bot. Estado

Sao Paulo 1: 245. 1926.

Fig. 21 

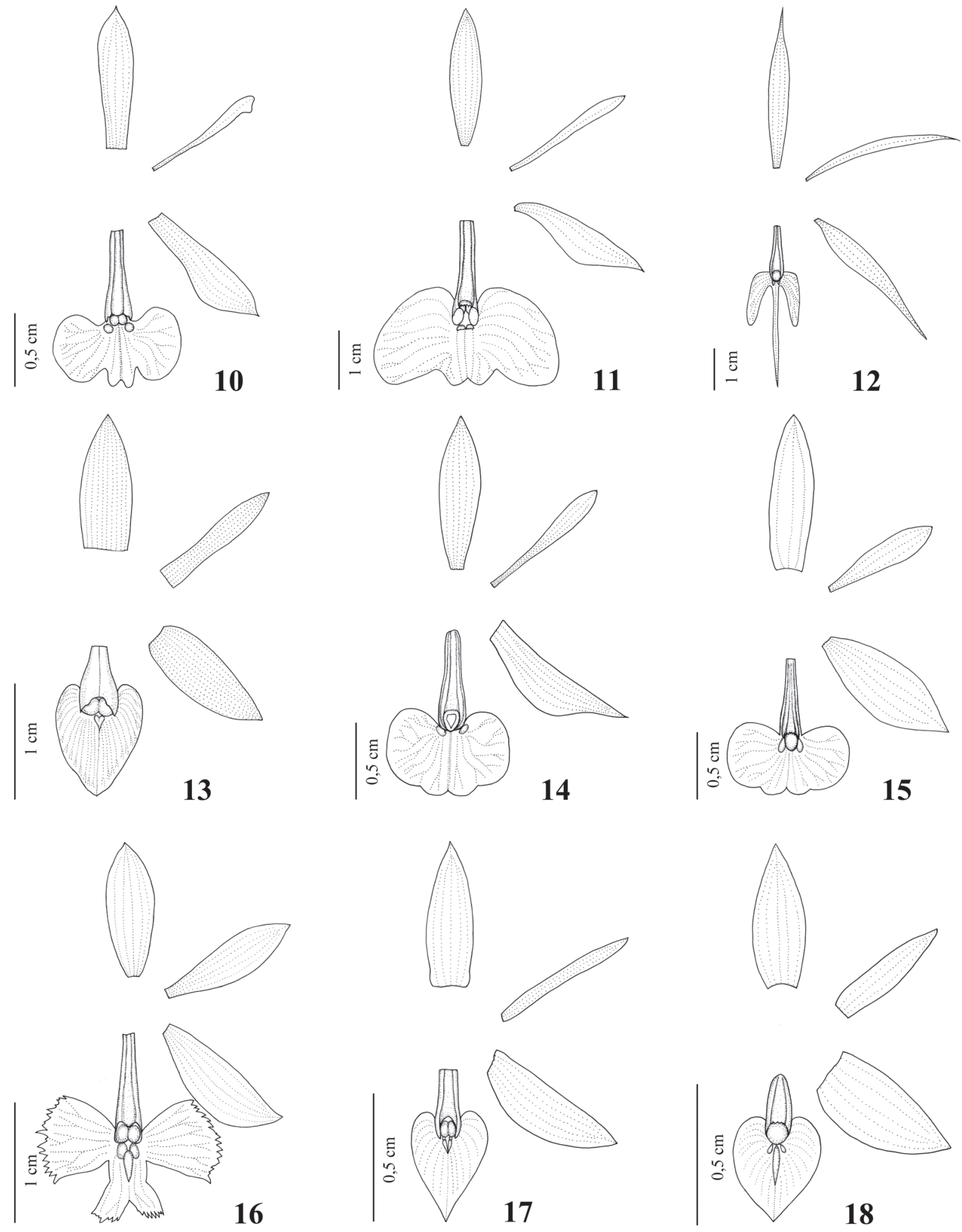

Figuras 10-18. Peças florais das espécies de Epidendrum no Paraná. 10. Epidendrum henschenii Barb. Rodr. (S. col. s.n. HB2117). 11. Epidendrum latilabre Lind1. (Stancik 14). 12. Epidendrum nocturnum Jacq. (Stancik 6). 13. Epidendrum paranaense Barb. Rodr. (Hatschbach 13582). 14. Epidendrum proligerum Barb. Rodr. (Hatschbach 2667). 15. Epidendrum pseudodifforme Hoehne \& Schltr. (Hatschbach 23336). 16. Epidendrum puniceoluteum F. Pinheiro \& F. Barros (Leinig 435). 17. Epidendrum ramosum Jacq. (Hatschbach 14388). 18. Epidendrum rigidum Jacq. (Hatschbach 39798). 
Terrestre, rupícola ou epífita, ereta. Caule $11-46 \mathrm{~cm}$ compr., simples, cilíndrico, $0,5-1 \mathrm{~cm}$ diâm., espessura constante; rizoma curto, ca. $0,7 \mathrm{~cm}$. Folhas 2,5-11,5×0,6-2,7 cm, dísticas, coriáceas, ovadas a lanceoladas, planas, ápice arredondado a agudo. Inflorescência 16-57 cm compr., em corimbo ou racemo, apical, ereta, base do pedúnculo envolvida por bainhas de 3-5 cm compr.; brácteas florais membranáceas, 0,1-0,5 cm compr., linear-triangulares a triangulares, cobrindo a base do pedicelo, ápice acuminado. Flores $12-80$ por inflorescência; pedicelo + ovário 1,6-2,7 cm compr., base não vesicada; sépalas lilases a róseas, a dorsal $0,6-1 \times$ $0,2-0,3 \mathrm{~cm}$, lanceolada a obovada, plana, ápice agudo, as laterais $0,7-1,1 \times 0,3-0,4 \mathrm{~cm}$, oblanceoladas, subfalcadas, planas, ápice agudo; pétalas $0,6-1,1 \times 0,15-0,3 \mathrm{~cm}$, lilases a róseas, elípticas a obovadas, margem inteira, ápice agudo; labelo 0,8-1,2×0,4-0,9 cm, lilás a róseo, delgado, plano, trilobado, lobos laterais suborbiculares a deltóides, margem erosa, lobo mediano retangular a deltóide, margem denticulada, ápice levemente mucronulado, calo alvo e/ou amarelo, inteiriço, ca. $0,1 \mathrm{~cm}$ compr., alongado, variadamente recortado, central; ginostêmio $0,35-0,5 \mathrm{~cm}$ compr. Fruto ca. $1,6 \times 0,8 \mathrm{~cm}$, fusiforme.

Material selecionado: BRASIL. Paraná: Adrianópolis, 11/I/2000, Isernhagen 310 (MBM); Antonina, 15/VIII/2003, Stancik 36 (UPCB); Balsa Nova, 20/VIII/1971, Hatschbach 26928 (MBM); Campina Grande do Sul, 26/VI/2003, Stancik 29 (UPCB); Campo Largo, 4/XII/1960, Leinig 225 (HB); Castro, 3/X/1964, Hatschbach 11673 (HB, MBM); Guaraqueçaba, 13/IX/1967, Hatschbach 17180 (MBM); Guaratuba, 12/XI/2003, Stancik 45 (UPCB); Jaguariaíva, 10/VII/2003, Stancik 33 (UPCB); Maringá, 3/VII/2002, Dora s.n. (HUM9198); Morretes, 6/II/1999, Pasdiora 1 (UPCB); Palmeira, 12/I/1966, Hatschbach 13502 (MBM); Piraí do Sul, 16/IV/1987, Kuniyoshi 5158 (MBM); Ponta Grossa, 17/XII/1903, Dusén s.n. (R3471); Quatro Barras, 28/VI/2003, Stancik 31 (UPCB); São José dos Pinhais, 23/VII/1998, Carneiro 503 (MBM); Sengés, 16/VI/1971, Hatschbach 26759 (MBM); Tibagi, 14/IV/2003, Stancik 12 (UPCB).

Observações: ocorre no México, Américas Central e do Sul, e em quase todo o Brasil. Coletada com flores em todos os meses do ano. No Paraná ocorre como epífita, terrestre ou rupícola em regiões de Floresta Ombrófila Densa de Terras Baixas, Submontana, Montana e Altomontana, Floresta Ombrófila Mista, Estepe e Floresta Estacional Semidecidual. Pertence a um grupo bastante complexo, a "Aliança E. denticulatum", do qual fazem parte E. ansiferum Rchb. f. e E. denticulatum Barb. Rodr., entre outras. Para maiores detalhes sobre a diferenciação destas espécies, ver comentários sob E. ansiferum e E. denticulatum. Além destas, também são citadas para o Paraná, por Pabst \& Dungs (1975), outras espécies do grupo: E. crassifolium Lindl. e E. ellipticum Grah., por exemplo. Todas compartilham, entre si, características intermediárias de caule, folhas e flores, dificultando a delimitação entre elas, devido à grande variação morfológica. Os exemplares analisados, referentes a estas espécies, apresentaram características em comum e de acordo com Pinheiro (F. Pinheiro, dados não publicados), devem ser consideradas como uma única espécie polimorfa, aplicando-se, neste caso, o nome Epidendrum secundum. Pabst \& Dungs (1975) posicionam E. secundum na "Aliança E. polyanthum", seguindo Garay \& Sweet (1974), que tratam pelo nome E. secundum, uma espécie diferente que seria identificada, mais corretamente, como E. anceps Jacq. Uma discussão mais detalhada sobre a utilização dos binômios E. secundum Jacq. e E. anceps Jacq. é apresentada por Hágsater (1993).

21. Epidendrum strobiliferum Rchb. f., Ned. Kruidk. Arch. 4:333. 1859.

Fig. 22

Epífita, pendente. Caule 2-12 cm compr., ramificado, compresso, 0,3-0,4 cm larg., espessura constante; rizoma curto, ca. $0,5 \mathrm{~cm}$. Folhas $0,7-2,8 \times 0,3-0,8 \mathrm{~cm}$, dísticas, coriáceas, ovadas, planas a ligeiramente conduplicadas, ápice agudo a arredondado. Inflorescência 1,6-2 cm compr., em racemo, apical, pendente, base do pedúnculo envolvida por 2 brácteas de ca. $0,5 \mathrm{~cm}$ compr.; brácteas florais cartáceas, 0,9-1,8 cm compr., ovadas, cobrindo o pedicelo e parte da flor, escondendo o eixo da inflorescência, ápice agudo a arredondado. Flores 3-6 por inflorescência; pedicelo + ovário ca. 0,6 cm compr., com base vesicada; sépalas alvacentas, a dorsal $0,4-0,5 \times \mathrm{ca} .0,15 \mathrm{~cm}$, elíptica, plana, ápice agudo, as laterais ca. $0,4 \times 0,15-0,2 \mathrm{~cm}$, ovadas, subfalcadas, planas, ápice agudo; pétalas ca. $0,4 \times 0,1 \mathrm{~cm}$, alvacentas, oblanceoladas, margem inteira, ápice agudo; labelo 0,4-0,5×ca. $0,2 \mathrm{~cm}$, alvacento, membranáceo, plano, inteiro, cordiforme, margem inteira, ápice agudo, calo ausente; ginostêmio ca. $0,2 \mathrm{~cm}$ compr., com 2 alas laterais. Fruto ca. $0,9 \times 0,5 \mathrm{~cm}$, globóide.

Material selecionado: BRASIL. Paraná: Antonina, 15/VIII/2003, Stancik 43 (UPCB); Guaraqueçaba, 3/II/1971, Hatschbach 26244 (MBM); Guaratuba, 6/I/1960, Leinig 170 (HB); Matinhos, 27/I/1951, Hatschbach 2123 (MBM); Morretes, 4/I/1978, Hatschbach 41835 (MBM); Morretes, 4/III/2003, Stancik 8 (UPCB); Paranaguá, 15/V/2003, Stancik 18 (UPCB); Pontal do Paraná, 26/I/2004, Stancik 52 (UPCB).

Observações: ocorre na Guiana Francesa e Brasil (RR, PA, AM, MT, GO, MG, RJ, SP, PR, SC). Coletada com flores em janeiro e fevereiro. No Paraná ocorre como epífita em locais sombreados em Floresta Ombrófila Densa de Terras Baixas e Submontana. Epidendrum rodriguesii Cogn., espécie próxima de E. strobiliferum, também é citada para o Paraná por Pabst \& Dungs (1975). Ambas apresentam características vegetativas e flores muito semelhantes, residindo a principal diferença no labelo, que em E. strobiliferum é inteiro e em E. rodriguesii é trilobado. Todos os materiais analisados atribuídos a essas duas espécies, são exemplares de E. strobiliferum, pois apresentam labelo inteiro. Supõe-se que a citação de E. rodriguesii para o estado se deva à identificação incorreta de exemplares de E. strobiliferum. 
22. Epidendrum vesicatum Lindl., Edwards's Bot. Reg. 24 (misc.): 50. 1838.

Fig. 23

Epífita, pendente. Caule 9-39 cm compr., simples, compresso, 0,7-0,8 cm larg., espessura constante; rizoma inconspícuo. Folhas 3,5-12,8×1,3-6 cm, equitantes, glaucas, cartáceas, elípticas a ovadas, fortemente imbricadas, côncavas, ápice agudo. Inflorescência ca. 5,5 cm compr., em corimbo, apical, pendente, base do pedúnculo envolvida por brácteas de 3-5,5 cm compr.; brácteas florais membranáceas, 0,3-0,4 cm compr., lanceoladas, cobrindo a base do pedicelo, ápice agudo. Flores 5-10 por inflorescência; pedicelo + ovário 2-3 cm compr., com base vesicada; sépalas verde-claras, a dorsal 0,7-0,8×ca. 0,3 cm, ovada, plana, ápice arredondado a agudo, as laterais ca. $0,7 \times 0,3 \mathrm{~cm}$, oblanceoladas, subfalcadas, levemente côncavas, ápice agudo; pétalas 0,6-0,8×ca. 0,1 cm, verde-claras, linear-oblanceoladas, margem inteira, ápice arredondado; labelo $0,8 \times 0,35 \mathrm{~cm}$, verde-claro, membranáceo, plano, inteiro, oblongo, margem inteira, ápice mucronulado, calo verde-claro, constituído de duas saliências ovóides, próximas entre si, ca. $0,01 \mathrm{~cm}$, basais; ginostêmio ca. $0,5 \mathrm{~cm}$ compr. Fruto não observado.

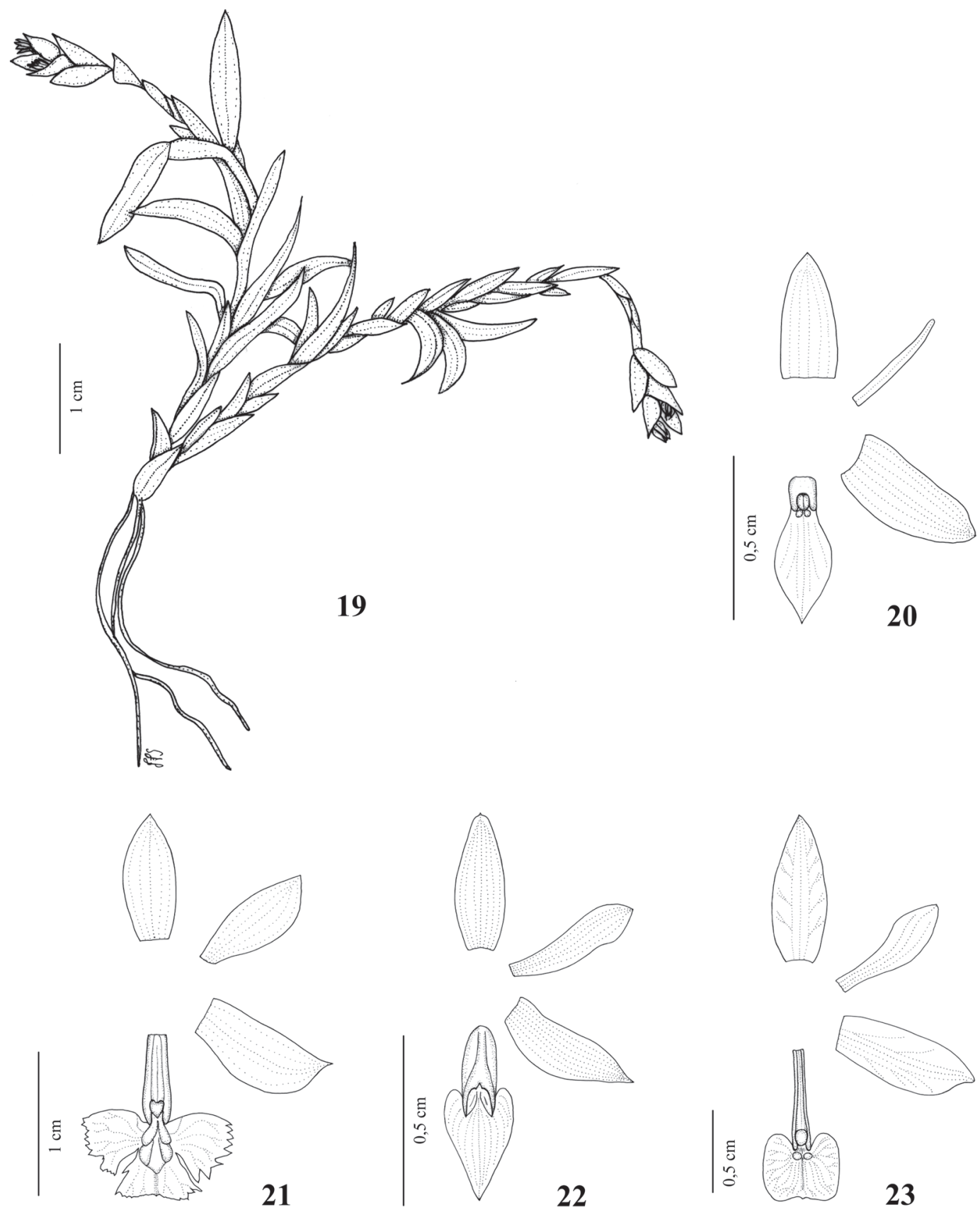

Figuras 19-20. Epidendrum saximontanum Pabst (Stancik 32). 19. Caule com folhas e inflorescência. 20. Peças florais. Figuras 21-23: Peças florais das espécies de Epidendrum no Paraná. 21. Epidendrum secundum Jacq. (Stancik 12). 22. Epidendrum strobiliferum Rchb. f. (Leinig 170). 23. Epidendrum vesicatum Lindl. (Hatschbach 11068). 
Material selecionado: BRASIL. Paraná: Campina Grande do Sul, 24/I/1964, Hatschbach 11068 (HB, MBM); Paranaguá, 31/III/1966, Hatschbach 14169 (MBM); Pontal do Paraná, 1/II/1966, Hatschbach 13653 (MBM).

Observações: ocorre no Brasil (BA, RJ, SP, PR, SC, RS). Coletada com flores entre janeiro e abril. No Paraná é pouco comum e por isso pouco coletada, ocorrendo como epífita em locais sombreados, em Floresta Ombrófila Densa de Terras Baixas e Montana e Floresta Ombrófila Mista. É uma planta facilmente reconhecida por seus caules pendentes com grandes folhas glaucas, côncavas, imbricadas, que encobrem a inflorescência. Apresenta flores de tonalidade verde-clara, as quais possuem ovário com base vesicada.

\section{Agradecimentos}

Juliane F. Stancik, Renato Goldenberg e Fábio de Barros agradecem as respectivas bolsas de Mestrado e de produtividade em pesquisa recebidas do CNPq.

\section{Referências bibliográficas}

Angely, J. 1956. Flora do Paraná: Orchidaceae Paranaenses. Revista do Instituto Paranaense de Botânica 6: 1-23.

Brieger, F.G. 1978. Über einige interessante Epidendrum-Arten der Subgenus Amphiglottium-Schistochila. Die Orchidee 29: 52-60.

Cogniaux, A. 1893-1896. Orchidaceae. Pp. 1-672, tab. 1-133. In: C.F.P Martius; A.G. Eichler \& I. Urban (eds.). Flora Brasiliensis v.3, pt. 4. München, Typographia Regia,.

Dodson, C.H. \& Dodson, P.M. 1980. 100 orchids of Lowland Ecuador. Tab. 301-400. In: C.H. Dodson (ed.). Icones Plantarum Tropicarum fasc. 4. Sarasota, The Marie Selby Botanical Gardens.

Dressler, R.L. 1981. The Orchids: Natural History and Classification. Cambridge, Harvard University Press.

Dressler, R.L. 1989. Will the real Epidendrum ibaguense please stand up? American Orchid Society Bulletin 58: 796-800.

Dressler, R.L. 1993. Phylogeny and classification of the orchid family. Cambridge, Cambridge University Press.

Dressler, R.L. 2005. How many orchid species? Selbyana 26: $155-158$

Dunsterville, G.C.K. 1979. Orchids of Venezuela - Epidendrum elongatum. American Orchid Society Bulletin 48: 447-454.
Garay, L.A. \& Sweet, H.R. 1974. Orchidaceae. Pp. 1-124 In: R.A. Howard (ed.). Flora of the Lesser Antilles: Leeward and Windward Islands v.8. Jamaica Plain, Arnold Arboretum.

Hágsater, E. 1993. Epidendrum anceps or Epidendrum secundum? Orquídea (Méx.) 13: 153-158.

Hágsater, E. (ed.). 2001. A third century of new species in Epidendrum. Icones Orchidacearum 4, part 3. México, Instituto Chinoin.

Hágsater, E.; Soto-Arenas, M.A.; Pridgeon, A.M.; Veitch, N.C. \& Grayer, R.J. 2005. Epidendrum. Pp. 236-251. In: A.M. Pridgeon; P.J. Cribb; M.W. Chase \& F.N. Rassmussen (eds.). Genera Orchidacearum v.4. Oxford, Oxford University Press.

Holmgren, P.K.; Holmgren, N.H. \& Barnett, L.C. 1990. Index Herbariorum: the herbaria of the world. $8^{\text {th }}$ ed. New York, New York Botanical Garden.

Maack, R. 1981. Geografia Física do Estado do Paraná. 2 ed. Curitiba, Secretaria da Cultura e do Esporte do Governo do Estado do Paraná.

Pabst, G.F.J. \& Dungs, F. 1975. Orchidaceae Brasilienses. Band 1. Hildesheim, Kurt Schmersow.

Pabst, G.F.J. \& Dungs, F. 1977. Orchidaceae Brasilienses. Band 2. Hildesheim, Kurt Schmersow.

Radford, E.A.; Dickison, W.C.; Massey, J.R. \& Bell, C. 1974. Vascular plant systematics. New York, Haper \& Row.

Rasmussen, F.N. 1985. Orchids. Pp. 249-274. In: R.M.T. Dahlgren; H.T. Cliford \& P.F. Yeo (eds.). The families of the Monocotyledons. Berlin, Springer-Verlag.

Roderjan, C.V.; Kuniyoshi, Y.S. \& Galvão, F. 1998. As regiões fitogeográficas do Estado do Paraná. Acta Florestalia Brasiliensis (Curitiba) 1: 1-6.

Saldaña, L.M.S. \& Hágsater, E. 1996. Taxonomic study of Epidendrum difforme group (Orchidaceae). Pp. 235-244. In: Proceedings of the $1^{\text {th }}$ World Orchid Conference, Rio de Janeiro. Turriers, Naturalia Publications.

Sastre, C. 1990a. Epidendrum bambusiformes de Guadeloupe et de Martinique. $1^{\mathrm{e}}$ partie. L'Orchidophile 93: 149-158.

Sastre, C. 1990b. Epidendrum bambusiformes de Guadeloupe et de Martinique. $2^{\mathrm{e}}$ partie. L'Orchidophile 94: 197-201.

Sastre, C. 1991. Meditations sur les orchidées bambusiformes du jardin de Claude French. L'Orchidophile 97: 107-108.

Schlechter, R. 1926. Orchidaceae Hatschbachianae. Repertorium Specierum Novarum Regni Vegetabilis 10: 10-60.

Schlechter, R. 1944. Contribuição ao conhecimento da flora orquidácea do Paraná. Orchidaceae Hatschbachianae. Orquídea (Rio de Janeiro) 7: 52-72.

Velloso, H.P.; Rangel Filho, A.L.R. \& Lima, J.C.A. 1991. Classificação da vegetação brasileira, adaptada a um sistema universal. Rio de Janeiro, Fundação IBGE. 